\title{
Hypothalamic neurohormones and immune responses
}

\section{J. Luis Quintanar* and Irene Guzmán-Soto}

Laboratory of Neurophysiology, Department of Physiology and Pharmacology, Centro de Ciencias Básicas, Universidad Autónoma de Aguascalientes, Aguascalientes, México

Edited by:

Beatriz Gomez-Gonzalez, Universidad Autonoma Metropolitana, México

\section{Reviewed by:}

Dumitru A. lacobas, Albert Einstein

College of Medicine of Yeshiva

University, USA

Fatih Tanriverdi, Erciyes University

Medical School Endocrinology

Department, Turkey

\section{*Correspondence:}

J. Luis Quintanar, Department of

Physiology and Pharmacology, Centro

de Ciencias Básicas, Universidad

Autónoma de Aguascalientes, Av.

Universidad 940, C.P. 20131,

Aguascalientes Ags., México

e-mail: jlquinta@correo.uaa.mx
The aim of this review is to provide a comprehensive examination of the current literature describing the neural-immune interactions, with emphasis on the most recent findings of the effects of neurohormones on immune system. Particularly, the role of hypothalamic hormones such as Thyrotropin-releasing hormone (TRH), Corticotropin-releasing hormone $(\mathrm{CRH})$ and Gonadotropin-releasing hormone $(\mathrm{GnRH})$. In the past few years, interest has been raised in extrapituitary actions of these neurohormones due to their receptors have been found in many non-pituitary tissues. Also, the receptors are present in immune cells, suggesting an autocrine or paracrine role within the immune system. In general, these neurohormones have been reported to exert immunomodulatory effects on cell proliferation, immune mediators release and cell function. The implications of these findings in understanding the network of hypothalamic neuropeptides and immune system are discussed.

Keywords: TRH, CRH, CRF, GnRH, LHRH, immune system, extrapituitary, receptors

\section{INTRODUCTION}

The neurosecretion in the hypothalamus can be traced back to the work of Scharrer and Scharrer (1940). Posterior studies by Harris specified that the hypothalamic substances secreted into the portal vessels were pituitary specific and propose the concept of "releasing factors" whose purpose was to initiate a cascade of events resulting in the release of peripherally active hormones (Harris, 1948).

The discovery and chemical characterization of the first identified hypothalamic releasing factor by Burgus et al. (1969) and Boler et al. (1969) provided ultimate confirmation for the founding principles of neuroendocrinology and was followed by the discovery of other peptide-releasing factors (Nillni and Sevarino, 1999).

\section{THYROTROPIN-RELEASING HORMONE (TRH)}

$\mathrm{TRH}$, the smallest known peptide hypophyseotropic hormone, is a tripeptide (pGlu-His-Pro- $\mathrm{NH}_{2}$; where pGlu stands for pyroglutamic acid) that is released from the hypothalamus and transported via the portal vascular system to the anterior pituitary where it stimulates the release of thyroid-stimulating hormone (TSH) and prolactin from the anterior pituitary (Matre et al., 2003).

TRH it is also known as thyrotropin-releasing factor (TRF), thyroliberin or protirelin (Khomane et al., 2011) and was the first chemically defined hypophyseotropic hormone (Bílek et al., 2011).

\section{SYNTHESIS}

This small tripeptide $(362.42 \mathrm{Da})$ is indeed processed from a larger precursor protein, prepro-TRH (ppTRH), through now classic cleavage mechanisms, C-terminal amidation, and cyclization of the N-terminal Gln to pGlu (Guillemin, 2005).

The rat ppTRH is a $29 \mathrm{kDa}$ polypeptide composed of 255 amino acids. The rat precursor contains an $\mathrm{N}$-terminal 25-aminoacid leader sequence, five copies of the TRH progenitor sequence Gln-His-Pro-Gly flanked by paired basic amino acids (Lys-Arg or Arg-Arg), four non-TRH peptides lying between the TRH progenitors, an $\mathrm{N}$-terminal flanking peptide, and a C-terminal flanking peptide. Rats and mice have five Gln-His-Pro-Gly TRH progenitor sequences, whereas humans have six TRH sequences (Chiamolera and Wondisford, 2009).

\section{TRH EXPRESSION REGULATION}

The maintenance of euthyroidism is dependent on a highly regulated balance of neuropeptides and neurotransmitters, where the dominant positive hypothalamic control for TSH is TRH, and the principal feedback control is through thyroid hormones (THs) (Nillni and Sevarino, 1999).

THs exert powerful feedback inhibition over the TRH response system by inhibiting TRH synthesis and processing in TRH neurons in the paraventricular region of the hypothalamus and decreasing TRH receptors (TRHR) and responses in the pituitary gland (Hinkle et al., 2012).

TRH gene expression is also regulated by temperature, food intake, and stress. Thus the TRH neuron is well positioned to integrate information about the environment as well as circulating TH levels and ultimately affect metabolism in response to these physiological changes (Chiamolera and Wondisford, 2009).

\section{HALF-LIFE}

The short half-life ( $4-5$ mins) of TRH is most likely due to rapid degradation of the TRH at both the carboxy $(\mathrm{COOH})$ and 
amino $\left(\mathrm{NH}_{2}\right)$ termini. Cleavage of the pyroglutamyl moiety of TRH by enzymes like aminopeptidases and deamidases causes formation of the metabolite histidyl proline diketopiperazine (ClycoHistine-Proline, CHP) while its deamidation results in the formation of the free acid, that is, TRH-OH (Khomane et al., 2011).

\section{TRHR}

The TRHR is a member of a large family of transmembrane proteins (G-protein-coupled receptors, GPCRs) for which an interaction with an intracellular $G$ protein is a critical part of the signal transduction pathway mediated by the receptor. It is thought that all GPCRs have a common tertiary structure composed of seven transmembrane helices. The topology of these membrane-bound proteins is defined by an extracellular amino terminus and an intracellular $\mathrm{COOH}$ terminus. Consequently, the helices are connected by intracellular-extracellular loops. Colson et al. (1998) suggested that TRH initially interacts with residues within the extracellular loops and then moves into the transmembrane binding pocket, aided by the motion of the loops.

A single TRHR gene has been found in humans and higher mammals and two genes encoding homologous receptors, TRHR1 and TRHR2, in rodents (Sun et al., 2003). TRHR1 predominates in the anterior pituitary gland while both TRHR1 and TRHR2 are found in rodent central nervous system (CNS) (Hinkle et al., 2012).

\section{EXTRAHYPOTHALAMIC AND EXTRAPITUITARY LOCATION OF TRH AND TRHR RESPECTIVELY}

Originally discovered in the hypothalamus, consistent with its classical role as a hypothalamic hypophysiotrophic factor, TRH and TRHR are now known to be distributed throughout the central and peripheral nervous system (PNS) and are found extensively in extrahypothalamic brain structures and in other organs and tissues (Sun et al., 2003; Kamath et al., 2009).

\section{TRH OUTSIDE THE PITUITARY ZONE}

$\mathrm{TRH}$ has been located in several brain areas other than the paraventricular nucleus as well as in non-CNS tissues:

- Pancreatic $\beta$-cells (Engler et al., 1981; Kawano et al., 1983).

- The whole gastrointestinal tract where it may modulate contractions (Morley, 1979; Engler et al., 1981).

- The genitourinary system. TRH is found in rat, canine and human prostate, seminal vesicles, ovary, testis, Leydig cells and epididymis (Pekary et al., 1980, 1983a,b; Feng et al., 1992).

- The presence of TRH in rat, human, porcine and bovine retina has been reported (Schaeffer et al., 1977; Martino et al., 1980a,b).

- Shambaugh et al. (1979) identified TRH activity in placental extracts by specific radioimmunoassay test (RIA).

- TRH has been found as part of immune system tissues and blood elements (Matre et al., 2003). This topic will be discussed in depth in the following sections.

\section{TRHR OUTSIDE THE HYPOTHALAMIC ZONE}

Besides the well-known TRHR location in the pituitary zone, TRH binding sites have been described throughout the central and PNS and in non-CNS tissues including:

- Uterus, ovary and testis where TRHR mRNA levels appear to be relatively high (Fukusumi et al., 1995; Montagne et al., 1999).

- Wang et al. (1997) reported that small intestine epithelial cells were found to express receptors for TRH and to be a primary source of intestine-derived TSH.

- TRHR is also found in retina (Satoh et al., 1993) and adrenal gland (Montagne et al., 1999).

Furthermore, TRHR expression in organs and cells of the immune system has been confirmed:

- Expression of TRHR mRNA and TRHR in lymphoid tissues has been found: Thymus, mesenteric lymph nodes and spleen (Raiden et al., 1995; Mellado et al., 1999).

- Thymus expression of the TRHR has been reported by several authors (Fukusumi et al., 1995; Mellado et al., 1999; Montagne et al., 1999; Matre et al., 2003).

- Expression analysis in rat demonstrated the presence of TRHR mRNA in bone marrow (Montagne et al., 1999; Matre et al., 2003) and in the rat natural-killer cell line RNK16 (Matre et al., 2003). This expression was shown to be functional as evidenced by $\mathrm{TRH}$ binding to surface receptors on thymocytes and RNK-16 cells.

- Analysis of human peripheral blood lymphocyte (Raiden et al., 1995; Mellado et al., 1999) and tonsil-derived leukocyte populations showed TRHR expression in non-activated and phytohemagglutinin-activated $\mathrm{T}$ and $\mathrm{B}$ cells (Mellado et al., 1999).

The widespread distribution of TRH and the TRHR within and outside the CNS supports a diverse range of roles for this molecule, roles likely to involve many functions outside of the traditional hypothalamic-pituitary-thyroid (HPT) axis (Nillni and Sevarino, 1999).

\section{TRH FUNCTIONS}

$\mathrm{TRH}$ indirectly stimulates $\mathrm{TH}$ biosynthesis and release. Thus, $\mathrm{TRH}$ is central in regulating the HPT axis. TRH influences the release of other hormones, including prolactin, growth hormone, vasopressin, insulin, and the classic neurotransmitters noradrenaline and adrenaline (Nillni and Sevarino, 1999).

\section{EXTRAHYPOPHYSIOTROPIC FUNCTIONS OF TRH}

More than two-thirds of immunoreactive-TRH in the brain is found outside of the traditional "thyrotrophic zone" of the hypothalamus. This extrahypophysiotropic TRH is believed to function as a neuromodulator of known neurotransmitters. Indeed, it might act as a neurotransmitter itself; it is present in secretory granules whose exocytosis is responsive to membrane depolarization, it acts through specific receptors that are widely distributed throughout the CNS, and it is rapidly cleared through specific catabolic pathways. In several areas of the brain, TRH is colocalized with other neurotransmitters and/or neuromodulators (Nillni and Sevarino, 1999). 
These effects of TRH have been demonstrated using TRH and/or TRH analogs. Available TRH analogs have higher affinities for the TRHR, longer half-lives, etc. (Engel et al., 2006; Khomane et al., 2011; Monga et al., 2011).

Beside endocrine functions, TRH also possesses several neuropharmacological effects like cerebral nerve activation (stimulation of motor function), effects on sympathetic nervous system (elevation of blood pressure and stimulation of respiratory), effects on spinal function (stimulation of spinal motor neuron), effects on CNS (antidepressant activity) and peripheral actions (suppression of gastric acid secretion, stimulation of glucagon secretion). These CNS-mediated effects provide the rationale for the use of TRH in the treatment of brain/spinal injury and certain CNS disorders, including schizophrenia, Alzheimer's disease, epilepsy, amyotrophic lateral sclerosis, Parkinson's disease and depression (Khomane et al., 2011).

\section{TRH AND IMMUNE SYSTEM}

Two-way communication between the immune and neuroendocrine systems is now well recognized. These interactions are mediated by cytokines, neuropeptides, hormones, other soluble factors and their receptors (Grasso et al., 1998).

As mentioned above, cells of the immune system have been found to contain receptors for neuroendocrine hormones and can also be considered a source of pituitary and hypothalamic peptides (Matre et al., 2003).

\section{IMMUNE RESPONSE TO TRH ADMINISTRATION Proliferation}

Induction. Acute and chronic administration of TRH enhances the proliferation of splenic and thymic lymphocytes in rats (Pawlikowski et al., 1992; Raiden et al., 1995; Winczyk and Pawlikowski, 2000). In fact, it has been reported that TRH promotes thymic reconstitution in mice with anterior hypothalamic area lesions (Lesnikov et al., 1991). According with these data, it was also reported that $\mathrm{TRH}$ enhances the in vitro plaque-forming cell response (Kruger et al., 1989), antagonizes the dexometasone-induced thymocyte and splenocyte suppression (Winczyk and Pawlikowski, 2000) and administration in humans led to increased secretion of IL-2 into the blood (Komorowski et al., 1993).

Suppression. It has also been reported that TRH significantly inhibits monocyte activity (Lersch et al., 1989). The experimental work of Kunert-Radek et al. (1991) addressed the proliferation of murine splenocytes in vitro considering the ${ }^{3} \mathrm{H}$-thymidine incorporation into splenocyte DNA as an index of proliferation. They found that TRH suppressed the proliferation of splenocytes.

TRH has the capability to modulate the natural cell-mediated cytotoxicity. To try it out, TRH was added to the feed of White Leghorn male chicks and peripheral blood lymphocytes were cultured in vitro with or without different mitogens (Phytohaemagglutinin-A (PHA), ConA, or Lipopolysaccharide (LPS)), and the culture supernatants were tested for the presence of lymphokines. Results showed that the supernatant from in vivo 5 ppm TRH-treated lymphocytes significantly suppressed the natural cell-mediated cytotoxicity (Haddad and Mashaly, 1992).
Recently was published that oral administration of TRH in mice with experimental autoimmune encephalomyelitis (EAE), an animal model of multiple sclerosis, reduces the spinal cord inflammatory foci without increased frequency of regulatory $\mathrm{T}$ cells (Treg) in spleen (Brod and Bauer, 2013).

\section{Induces TSH production by immune cells}

At very low concentrations, TRH induces splenocyte production of TSH in vitro (Kruger et al., 1989).

Peripheral blood mononuclear cells (PBMC), rat splenocytes and transformed $\mathrm{T}$ cell lines produce TSH in response to TRH (Harbour et al., 1989; Raiden et al., 1995).

\section{Induces immune mediators production}

PBMC, rat splenocytes and transformed $\mathrm{T}$ cell lines can enhance or modulate the in vitro antibody response in response to TRH (Kruger et al., 1989; Hart et al., 1990).

Koshida and Kotake (1993) investigated the role of TRH on the superoxide anion $\left(\mathrm{O}_{2}{ }^{-}\right)$production of rabbit peritoneal macrophages. Their results showed that TRH acts on macrophages and suggest that TRH possesses the priming action of $\mathrm{O}_{2}{ }^{-}$release in response to the chemotactic peptide $\mathrm{N}$ formyl-methionyl-leucyl-phenylalanine, and opsonized zymosan. Authors suggest that if this type of priming exists in vivo there should be a role to play in an inflammation process.

In vitro studies have shown that a $\mathrm{TRH}$ fixation occurs at the level of the human polymorphonuclear neutrophil, which suggests putative membrane receptor (s) for the hypothalamic hormone. The correspondent in vivo analyses demonstrated that after TRH administration, enzyme modifications (myeloperoxydase, alkaline phosphatase) and metabolism changes (PAS, Sudan black) happen, showing a functional activation of that blood cell (Blum et al., 1976). These in vivo effects could be due to TRH is being directly attached to its receptor on neutrophils or an indirect effect is being mediated by TSH or THs.

Intravenous bolus of TRH in normoprolactinemic women increases plasma gamma interferon (IFN- $\gamma$ ) levels 45 mins after administration. In order to investigate a possible direct action of TRH on immune cells, the authors also examined the effects of this hypothalamic peptide on IFN- $\gamma$ production by PBMCs stimulated in vitro with suboptimal concentration of bacterial superantigen staphylococcal enterotoxin A or concanavalin A (ConA), collected before the intravenous administration of TRH. The in vitro findings showed a directly enhanced IFN- $\gamma$ production by activated lymphocytes (Grasso et al., 1998).

Furthermore, splenic and CNS lymphocytes showed significant decrease in levels of profile 17 helper $\mathrm{t}$ cells $\left(\mathrm{T}_{H} 17\right)$ and $\mathrm{T}_{H} 1$ cytokines: Interleukin-17 (IL-17), tumor necrosis factor (TNF- $\alpha$ ) and IL-2 respectively, after oral administration of TRH in EAE mice. This treatment also increased CNS lymphocyte production of $\mathrm{T}_{H} 2$ cytokines, in particular IL-13 (Brod and Bauer, 2013). Thus, oral TRH shows a unique pattern of immunomodulation for an ingested neuropeptide although the poor oral bioavailability associated with TRH and some of its analogs (Khomane et al., 2011). 


\section{TRH expression response against immune system challenges}

It is known that high concentrations of TRH seem to decrease the production of antibodies against sheep red blood cells (SRBC) (Kukain et al., 1982).

Pérez Castro et al. (1999) investigated whether TRH mRNA levels in the hypothalamus are altered after SRBC (a T celldependent antigen) immunization. An increased level of TRH mRNA detected by Northern blot autoradiography was observed at 4,6 , and 24 h post immunization in SRBC-injected animals.

The SRBC-induced effects on TRH mRNA levels are opposite to those induced by LPS, a T cell-independent response through macrophage and B lymphocyte activation. LPS induces a decrease in hypothalamic TRH mRNA levels that is observed at $24 \mathrm{~h}$ and more pronounced at $4 \mathrm{~h}$ (Pérez Castro et al., 1999).

As we can see, TRH effects could seem controversial but is important to consider that interactions between the CNS, the endocrine system and the immune system are mediated at multiple levels. These mediators include secreted chemical messengers such as hormones, cytokines, neurotransmitters and neuropeptides acting directly or via the nervous system.

Evidence indicates interactions at the level of receptors (e.g., the presence of neuroendocrine peptide receptors on immune cells), at the level of secretory function (e.g., the synthesis and secretion of neuroendocrine peptides by immune cells), and at the level of signal transduction (Kamath et al., 2009). Integration of these complex interactions in a single route would be inaccurate, for this reason, the most wise conclusion could be consider the TRH-immune system homeostatic hypothesis proposed by Gary et al. (2003) and Kamath et al. (2009), which states that TRH mediated mechanisms respond to many elements of the immune system and affect them in ways that tend to maintain or restore homeostasis.

The effects of TRH administration on immune system are summarized in Figure 1.

\section{CLINICAL RELEVANCE AND FUTURE DIRECTIONS}

Studies on the effects of TRH in vitro hardly can be extrapolated to in vivo conditions. The direct effect of TRH on the immune system provides a modulatory physiological role. However, pharmacological administration in humans and in experimental animals involves two pathways impact (1) through stimulation of TSH secretion and therefore of THs and (2) the direct effect on the immune system. TRH administration may affect these two ways and with addition or synergy effects. One possibility to explore the direct mode might be using hypophysectomized or thyroidectomized animals to avoid endocrine influence. According to the studies described above, it is possible to consider the possibility that clinical treatment with TRH may improve the immune response in patients with immune deficiencies or reduced response in autoimmune diseases such as multiple sclerosis or lupus erythematosus. Such expectations are a challenge to be explored in the future.

\section{CORTICOTROPIN-RELEASING HORMONE (CRH)}

CRH or Corticotropin-releasing factor (CRF) was characterized, purified and synthesized in 1981 by Vale. The composition of this 41 amino-acid peptide is different from one species to another.
Its principal origin in the brain are the neurons from paraventricular nucleus of the hypothalamus. By the portal hypothalamicpituitary vessels, it reaches the anterior pituitary lobe where it stimulates the corticotroph cells (Raux-Demay and Girard, 1985; Emeric-Sauval, 1986). The plasma half-life of CRH in humans is 4 mins (Schürmeyer et al., 1984). The action of CRH on adrenocorticotrophic hormone (ACTH) secretion is predominant, but it acts in relation with arginine-vasopressin and potentially with angiotensin and catecholamines. Adrenal steroids (glucocorticoids) act on feedback control of CRH secretion in the hypothalamus and also on pituitary corticotrophs. CRH has shown to be an important regulator of the endocrine stress response, and it is now known to play a role in diverse functions in the homeostatic balance, important in mobilization of resources and behaviors during stress (Bale and Vale, 2004), it is involved in the regulation of food intake and satiety, as well as gastrointestinal tract motility, vascular tone, and development, and also acoustic and cardiac function (Heinrichs et al., 1992; Koob and Heinrichs, 1999; Maillot et al., 2000; Inoue et al., 2003; Janssen and Kozicz, 2013).

\section{CRH RECEPTOR (CRHR)}

High-affinity CRHRs which mediate the actions of the hypothalamic peptide on ACTH release, have been principal identified in the anterior pituitary gland. Interaction of the pituitary receptor by $\mathrm{CRH}$ agonists stimulates ACTH release. CRH exerts its effects by binding to specific cell surface receptors, of which two receptor subtypes have been reported, CRH-R1 and CRH-R2. These receptors share high sequence homology and belong to the family of seven transmembrane GPCRs (Vaughan et al., 1995; Lewis et al., 2001).

Actions of this peptide are initiated by binding and activating GPCRs and subsequently the activation of adenylate cyclase and cyclic adenosine monophosphate dependent protein kinase (Grammatopoulos and Chrousos, 2002). In the regulation of ACTH secretion, the effects of CRH on the corticotroph are integrated with the stimulatory actions of cyclic adenosine monophosphate and the inhibitory effects of glucocorticoids. Following adrenalectomy, the progressive elevation of plasma ACTH levels is accompanied by a concomitant decrease in pituitary CRHRs (down-regulation) (Wynn et al., 1985; Aguilera et al., 1986).

\section{Extrapituitary expression of CRHR}

CRH-R1 is a 415 amino acid peptide and has a widespread expression in stress-related areas located in the CNS (Justice et al., 2008; Kuhne et al., 2012). Outside the CNS, the CRH-R1 is expressed in the adrenal gland, gastrointestinal tissue, ovary, testis, skin, thymus and spleen (Dufau et al., 1993; Nappi and Rivest, 1995; Slominski et al., 1995; Baigent and Lowry, 2000; Müller et al., 2001; Chatzaki et al., 2004). CRH-R2 is a 397-437 amino acid protein and it is abundantly expressed in the CNS (Korosi et al., 2007; Justice et al., 2008; Kuhne et al., 2012). In the periphery, the receptor has been identified in the retina, heart, skeletal muscle, vasculature, adrenal gland, and gastrointestinal tissue (Lovenberg et al., 1995; Müller et al., 2001; Chatzaki et al., 2004). 


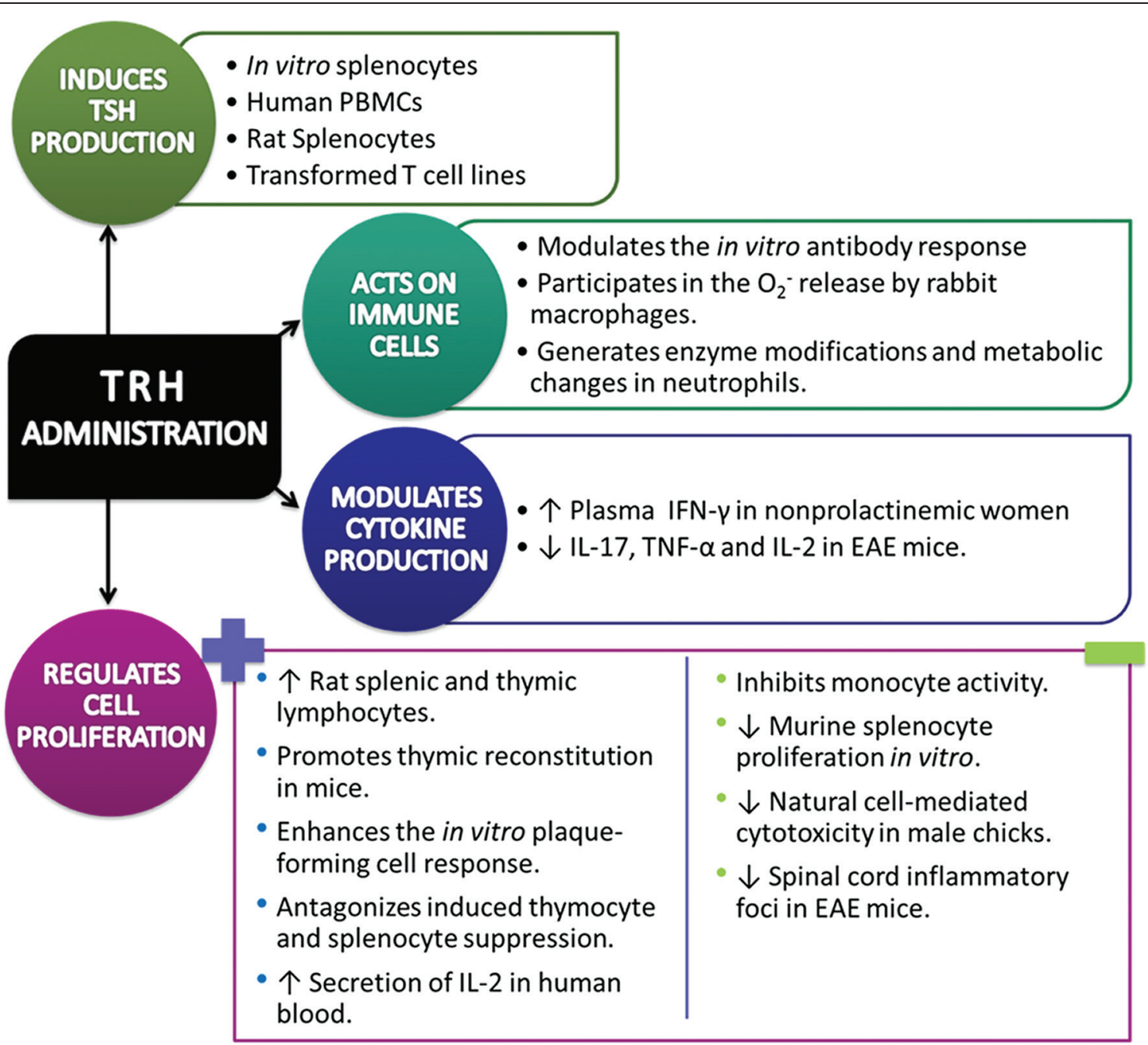

FIGURE 1 | Immune response against Thyrotropin-Releasing Hormone/Thyrotropin-Releasing Hormone agonist administration in a diversity of normal and pathological conditions $(\uparrow=$ increase, $\downarrow=$ decrease $)$.

Binding sites for $\mathrm{CRH}$ have been reported on adherent splenocytes (Webster et al., 1990), monocyte-macrophages (Audhya et al., 1991) and T lymphocytes (Singh and Fudenberg, 1988). CRH-R1 and CRH-R2 expression was described in granulocytes and lymphocytes in inflamed tissues (Mousa et al., 2003). CRH-R1 mRNA expression had been reported in the human leukemic mast cell line (Theoharides et al., 1998) and mast cells were reported to express immunoreactive CRH-R1 in inflamed human synovial tissue (McEvoy et al., 2001).

\section{CRH EFFECTS ON CNS AND PNS}

Independently of anterior pituitary, CRH has effects within of nervous system. The central administration of $\mathrm{CRH}$ produces hypertension, tachycardia and an elevated oxygen consumption. CRF acts within the brain to increase plasma concentrations of noradrenaline and adrenaline resulting in increased plasma concentrations of glucagon and in hyperglycemia. Likewise, also acts increasing the plasma concentrations of vasopressin. $\mathrm{CRH}$ induces a reduction in food intake and increases grooming behavior and locomotor activity. The physiological significance of the peripheral actions of CRH on various organ systems is unknown. Intravenous administration of $\mathrm{CRH}$ reduces gastric acid secretion, gastric emptying and blood pressure but increases heart rate, venous return to the heart, mesenteric and aortic blood flow and pancreatic bicarbonate and protein secretions (Lenz, 1987; Chen et al., 2007).

\section{CRH AND IMMUNE SYSTEM}

The cellular components of the immune-inflammatory response include leukocytes, such as monocytes-macrophages, polymorphonuclear neutrophils, eosinophils and basophils, platelets, dentritic cells, mast cells, epithelial and endothelial cells, and fibroblasts which belong to the innate immune system, as well as lymphocytes T, B and natural killer (NK) which are included in the adaptive immune system. These cells cooperate using molecular signals, including ILs, colony-stimulating factors, TNF, IFNs, 
transforming growth factor, and chemokines, vasoactive amines (histamine and serotonine), plasma proteases (kinine and complement systems), arachidonic acid metabolites (prostaglandins, leukotrienes, and lipoxins), platelet-activating factor, nitric oxide, and neuropeptides (Mastorakos et al., 2006).

The majority of in vivo studies suggest that direct stimulation of hypothalamic CRH by cytokines is the principal route by which immune activation stimulates the hypothalamic-pituitaryadrenal (HPA) axis (Besedovsky et al., 1986; Harbuz et al., 1992) and this process is prostaglandin-dependent. Thus, experimental evidence suggests that CRH may modulate the immune and inflammatory responses via two pathways: an anti-inflammatory one operated by centrally released $\mathrm{CRH}$, most likely through stimulation of glucocorticoid and catecholamine release, and one pro-inflammatory, through direct action of peripherally secreted CRH (Karalis et al., 1997).

\section{CRH in immune cells}

Mast cells. Mast cells are critical for allergic reactions due to their secretion of numerous vasoactive molecules and cytokines (Kobayashi et al., 2000). Evidence indicates that mast cells are also involved in innate and acquired immunity (Marone et al., 2002), as well as in neuroinflammatory conditions such as those affected by stress (Theoharides and Cochrane, 2004). Mast cells secrete numerous pro-inflammatory cytokines, such as IL-6, IL8, and TNF- $\alpha$ (Kobayashi et al., 2000; Marone et al., 2002), and secretion of vascular endothelial growth factor (VEGF) by $\mathrm{CRH}$ stimulation (Cao et al., 2005). Interestingly, human mast cells were shown to synthesize and secrete large amounts of $\mathrm{CRH}$, suggesting that this peptide could regulate mast cells through $\mathrm{CRH}$ receptor in an autocrine manner. Secretion of $\mathrm{CRH}$ from mast cells could also be triggered by pro-inflammatory molecules that are released during the initial phases of inflammation (Kempuraj et al., 2004). CRH causes mast cell degranulation in human skin, releasing great amounts of histamine, which appears to be the principal mediator of the vasodilatory effects of $\mathrm{CRH}$ (Wright, 2003).

Mononuclear cells. In mononuclear cells, it has been reported that $\mathrm{CRH}$ stimulates immune functions, proliferation of lymphocytes both in the absence and presence of $\mathrm{T}$ cell mitogens, and the expression of IL-2R antigen on T cells (Singh, 1989; Singh et al., 1990). It has also been reported the presence of binding sites for $\mathrm{CRH}$ on monocytes, $\mathrm{T}$ and $\mathrm{B}$ lymphocytes and thymus (Singh and Fudenberg, 1988). The CRH is also a stimulator of production of two interleukins, IL-1 and IL-2. IL-1 has been shown to stimulate the secretion of $\mathrm{CRH}$ by hypothalamic cells (Sapolsky et al., 1987) and CRH stimulates the production of IL-1 and IL-2, suggesting the presence of a complete network between the neuroendocrine system and the immune system (Singh and Leu, 1990).

The release of CRH plays a role in modulating NK activity following stress also implies that $\mathrm{CRH}$ in the brain may be involved in the functional population of lymphocytes. Studies have been conducted to analyze the effect of CRF on the reduction of several cellular immune measures such as splenic and peripheral blood NK activity and lymphocyte responses to mitogenic stimulation (Strausbaug and Irwin, 1992;
Boyadjieva et al., 2006). Other observations also indicate that central doses of $\mathrm{CRH}$ slow the kinetics and reduce the level of IgG response to a specific T-cell-dependent antigen (Irwin, 1993). The administration of central CRH antagonist induces suppression of NK cytotoxicity. In contrast, peripheral application has no effect on CRH modulation of immunity (Irwin et al., 1987).

Other studies have shown CRH to inhibit IFN- $\gamma$ secretion (Angioni et al., 1993). IL-2-induced splenocyte proliferation as well as LPS-mediated IL-1 and IL-6 production by peripheral blood monocytes (Hagan et al., 1992).

The effects of CRH were almost exclusively examined in the mononuclear cells, however in other studies has been reported that polymorphonuclear cells (neutrophils), express higher levels of CRH-R1 than mononuclear immune cells in mouse (Radulovic et al., 1999). It has been shown that CRH inhibits the secretion of IL- $1 \beta$ from mature neutrophils purified from spleens of mice injected with LPS (Radulovic and Spiess, 2001).

It has been described the $\mathrm{CRH}$ presence in macrophages (Brouxhon et al., 1998). Results showed that CRH could be detected in normal peritoneal macrophages and the levels increased significantly after stimulation with LPS (Wang et al., 2012). The role of CRH may be immunomodulatory, however the effects remains to be studied.

On other hand, studies shown that cluster of differentiation $(\mathrm{CD} 14+)$ group of cell surface marker proteins, the $\mathrm{CRH}$ can activate CD14+ cells to produce TNF- $\alpha$ cells and compromise endothelial barrier function by inducing apoptosis of the endothelial cells (Song et al., 2013).

\section{CRH and its relationship to immune therapies}

Drugs have been proposed to either block CRHR-1 and CRHR-2 receptors as $\mathrm{CRH}$ inhibitors with therapeutic properties through modifying the immune response as tool for both CNS and inflammatory disorders associated with central and peripheral CRH. CRH-R1 antagonist could be considered for the treatment of allergic conditions, such as urticaria, asthma, eczema, or disorders that increase blood-brain barrier permeability (Theoharides et al., 1998; Esposito et al., 2002), chronic inflammatory bowel syndromes, irritable bowel disease, and ulcerative colitis and other pathologies (Kawahito et al., 1995; Gravanis and Margioris, 2005).

The effects of CRH administration on immune system are summarized in Figure 2.

\section{Future directions}

There are two major problems associated with the HPA axis. The inflammatory process and the reduction in the immune response. Chronic exposure to antiinflammatory steroids have effects such as immunosuppression which under certain conditions can cause undesired effect. Identifying specific receptor subtypes to $\mathrm{CRH}$, or applying interleukin receptor blockers may provide a viable alternative to maintaining of the homeostatic mechanisms.

Emotional stress causes somatic alterations including the immune response and is perhaps, one of the most pressing problems in global public health that needs to be addressed. 


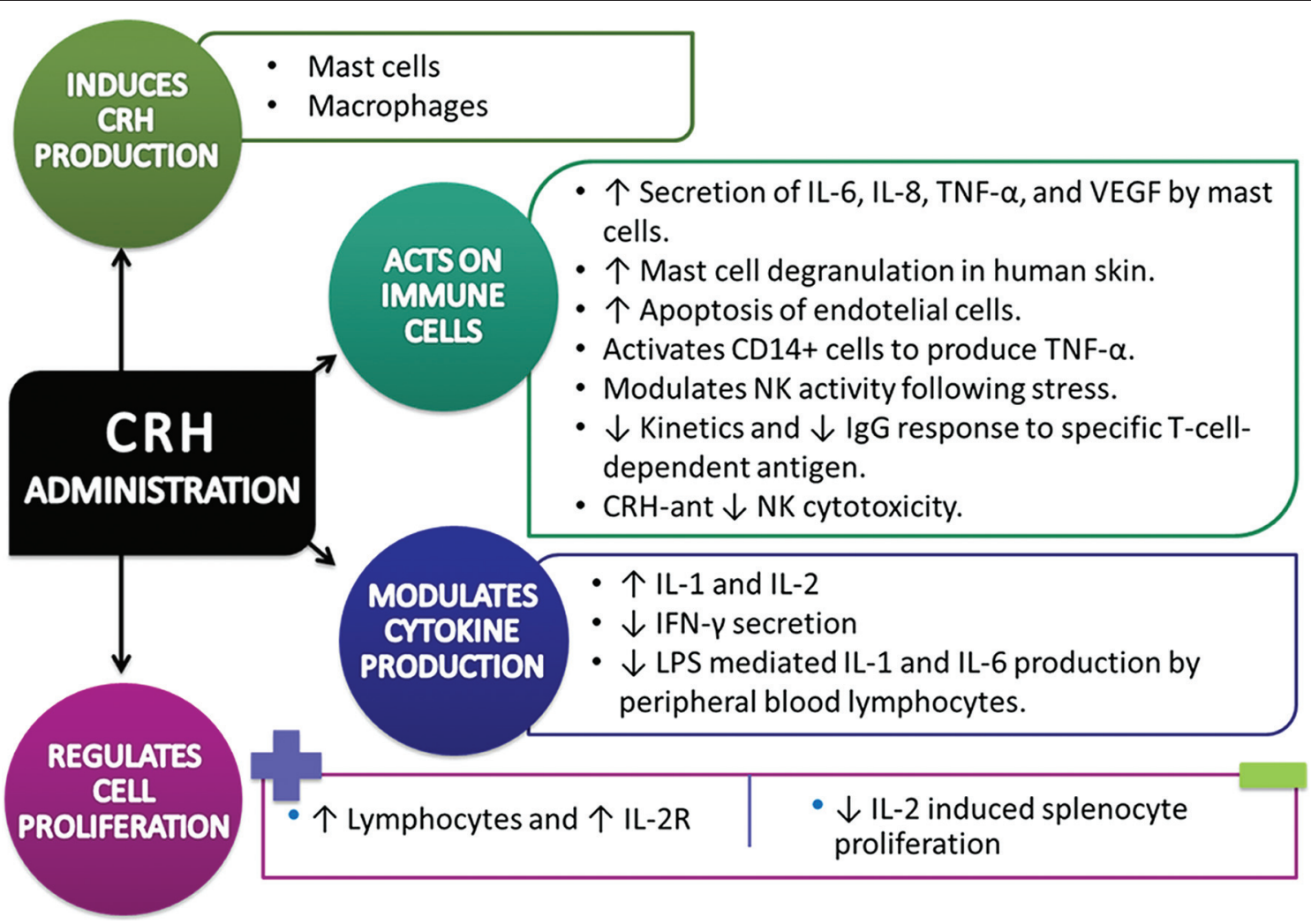

FIGURE 2 | Experimental data of Corticotropin-Releasing Hormone/Corticotropin-Releasing Hormone agonist impact on immune system cells and processes $(\uparrow=$ increase, $\downarrow=$ decrease $)$.

\section{GONADOTROPIN-RELEASING HORMONE (GnRH)}

$\mathrm{GnRH}$, also known as luteinizing hormone releasing hormone (LHRH), is a small peptide hormone (pGlu-His-Trp-Ser-Tyr-GlyLeu-Arg-Pro-Gly- $\mathrm{NH}_{2}$ ) of $1.2 \mathrm{kDa}$, with an established role as central regulator of the neuroendocrine reproductive axis in both males and females (Cheung and Wong, 2008).

This neuropeptide is mainly synthesized in hypothalamic neurons of the medial preoptic area. It is well established that adenohypophysial gonadotropic cells stimulate the synthesis and secretion of gonadotropic hormones such as follicle stimulating hormone (FSH) and luteinizing hormone (LH) (Cheng and Leung, 2005). LH and FSH are released into the systemic circulation in a pulsatile pattern, which is dependent upon the GnRH pulse frequency, and act to affect gonadal steroidogenesis and gametogenesis (Sasaki and Norwitz, 2011).

\section{GnRH ISOFORMS}

At the present, it is known that, in addition to the hypothalamic GnRH, several other isoforms of the decapeptide exist in vertebrates. All these isoforms are characterized by the conservation of the length of the peptide as well as by the amino acid sequences of the N-terminal (Glp-His-Trp-Ser) and C-terminal (Pro-Gly- $\mathrm{NH}_{2}$ ) domains, indicating that these molecular features are critical for the binding to, and the activation of, the receptor (Limonta and Manea, 2013). The classical hypophysiotropic
$\mathrm{GnRH}$ located in the anterior hypothalamus/preoptic area is also designed as GnRH-I (Stevenson et al., 2012).

A second isoform of $\mathrm{GnRH}$, originally isolated from the chicken hypothalamus and referred to as chicken $\mathrm{GnRH}$ or cGnRH, has been isolated in most vertebrate species-including humans-is now referred to as GnRH-II and is 70\% homologous to GnRH-I (Sasaki and Norwitz, 2011). GnRH-II is expressed at a higher level outside of the brain (Tan and Bukulmez, 2011).

A third GnRH isoform, GnRH-III, was isolated from sea lamprey and was also detected in the brain of mammals (Tan and Bukulmez, 2011). This isoform has 60\% homology with GnRH-I. In the lamprey, GnRH-III is localized in brain areas involved in the control of reproductive functions and it has been reported to stimulate steroidogenesis and gametogenesis, but it has 500-1000 times less potency in LH and FSH secretion both in vitro and in vivo (Limonta and Manea, 2013).

$\mathrm{GnRH}$ is small and has good thermal and chemical stability and no internal Cys bridges (minimal fixed structure). Its size and stability has led to the availability of thousands of analogs (Conn and Janovick, 2009).

\section{SYNTHESIS AND SECRETION}

$\mathrm{GnRH}$ is synthesized as a prohormone, human preproGnRH that contains 92 amino acids (Harrison et al., 2004). The gene encoding preproGnRH1 gene has been cloned in number of species and 
is approximately 4300-bp with four relatively short exons separated by three large introns (Clarke and Pompolo, 2005).

Neurons that synthesize and release GnRH (GnRHergic neurons) have their origin in embryonic olfactory placodes. These embryonic cells, migrate and colonize the basal forebrain, preoptic area around the basal and medium hypothalamus. The median eminence in mammals contains a large amount of $\mathrm{GnRH}$, so is the area in which the peptide is stored in neural terminals before release into the hypothalamus-pituitary portal system (Clarke and Pompolo, 2005).

$\mathrm{GnRH}$ is released as synchronized pulses from the nerve endings of about 1000 neurons into the hypophyseal portal system every 30-120 mins to stimulate the biosynthesis and secretion of LH and FSH from gonadotrophs (Millar, 2005). In adult rodents, $\mathrm{GnRH}$ is released from the median eminence at a frequency of about one pulse every 30 mins. A slightly slower frequency of release (approximately 50-60 mins intervals) is observed in primates (Yin and Gore, 2006). On the other hand, continuous (non-pulsatile) GnRH administration or long-lasting GnRH-a desensitize GnRHR, thereby decreasing/inhibiting the release of LH and FSH by the pituitary (Wilson et al., 2007).

\section{HALF-LIFE}

GnRH half-life normally is about 2-4 mins (Walters et al., 2008). Its short half-life is because of the rapid cleavage of the bonds between amino acids at positions 5-6, 6-7, and 9-10. Substitution at position 6 in $\mathrm{GnRH}$ agonists ( $\mathrm{GnRH}-\mathrm{a})$ yields them resistant to degradation and increases its half-life and the time of receptor occupancy (Magon, 2011).

\section{GnRH RECEPTOR (GnRHR)}

The human pituitary GnRHR belongs to the family of GPCRs and is one of the smallest GPCRs (328 amino acid protein in the human); it may contain only the essentials required for ligand binding and signal transduction (Conn and Janovick, 2009).

Distinct forms of the GnRHR can be broadly divided into two groups:

1. The type I GnRH-Rs have greater affinity for GnRH-I than for GnRH-II and lacks a typical intracellular COOH terminus; this group contains all known mammalian GnRH-Rs except for the recently described primate type II GnRH-R (McArdle et al., 2002; Ciechanowska et al., 2010).

2. Type II GnRH-Rs have greater affinity for the GnRH-II and possess C-terminal tails of varying length; this group contains all the known receptors from non-mammalian vertebrates (catfish, goldfish, chicken, goldfish, Xenopus, etc.) in addition to the type II primate GnRH-Rs (McArdle et al., 2002).

\section{EXTRAHYPOTHALAMIC AND EXTRAPITUITARY LOCATION OF GnRH AND GnRHR RESPECTIVELY \\ GnRH outside the pituitary zone}

GnRH has been located in several extrahypothalamic cells and tissues: GnRH-like substances have been reported to be secreted from tissues outside the CNS of rats and humans. Particularly, a $(\mathrm{GnRH})$-like protein has been detected in human ovaries (Aten et al., 1987; Dong et al., 1993; Peng et al., 1994). Also, Oikawa demonstrated by PCR amplification of cDNA from rat hypothalamus, granulosa cells, and whole ovary, a 241-bp prod- uct identical to the authentic GnRH sequence based on analysis on both strands (Oikawa et al., 1990).

RT-PCR analysis together with Southern blot analysis demonstrated the presence of GnRH mRNA in human testes and mammary gland (Dong et al., 1993).

Furthermore, the gene coding for $\mathrm{GnRH}$ is expressed in immune tissue and immunoreactive $\mathrm{GnRH}$ is measurable in immune cells. Analysis of mononuclear cells by RT-PCR coupled to Southern hybridization of total RNA confirmed that GnRH genes are expressed in human peripheral blood lymphocytes. The GnRH transcripts in mononuclear cells were identical to the hypothalamic GnRH and PRL release inhibiting factor cDNA, at least within this 380-bp fragment (Chen et al., 1999).

Rat splenocytes contain an immunoactive and bioactive $\mathrm{GnRH}$ (Emanuele et al., 1990; Azad et al., 1991) that has also been found in lymphocytes from rat thymus (Marchetti et al., 1990; Maier et al., 1992). Moreover, it has been reported that normal and leukemic human T cells produce GnRH-II and GnRH-I and that the incubation of those cells with these neuropeptides triggered de novo gene transcription and cell-surface expression of a $67-\mathrm{kDa}$ non-integrin laminin receptor that is involved in cellular adhesion and migration and in tumor invasion and metastasis (Chen et al., 2002).

The fact that recent evidence shows the existence of diverse isoforms of GnRH, with high sequence homology and a core variable region raises the issue that previous $\mathrm{GnRH}$ distribution studies may have identified a variety of isoforms. To confirm the distribution of GnRH-I only, Khan et al. (2003), reported that intense GnRH-I immunoreactivity was found in Kupffer cells, and less intense in spleen lymphocytes and follicular dendritic cells in rat.

Other cells that have been reported to express $\mathrm{GnRH}$ and its mRNA are mast cells from the nervous system and the peritoneal cavity, as detected by immunohistochemistry and RTPCR, respectively (Silverman et al., 1994; Gill and Rissman, 1998; Khalil et al., 2003).

\section{Extrapituitary GnRHR}

GnRH binding sites have been described throughout the CNS and PNS as in several non-CNS cells and tissues:

Human ovarian granulosa-luteal cells also express the GnRHR mRNA (Chen et al., 1999).

GnRHR expression in organs and cells of the immune system has been confirmed: GnRH binding sites have been reported in rat spleen (Batticane et al., 1991) and thymus, thus potentially enabling GnRH-a to have direct stimulatory effects that might contribute to improved T-cell function (Marchetti et al., 1989; Batticane et al., 1991; Morale et al., 1991).

RT-PCR coupled to Southern hybridization of total RNA obtained from mononuclear cells confirmed that the GnRHR is expressed in human peripheral blood lymphocytes (Chen et al., 1999) as in porcine lymphocytes (Standaert et al., 1992).

Chen and colleagues reported that the GnRHR transcript expressed in mononuclear cells has an identical nucleotide sequence as the pituitary GnRHR cDNA. In this work, a time-course study of the effect of GnRH on mononuclear cells was performed and it was found that GnRHR mRNA increased gradually after in vitro culture, and this increase was further augmented by treatment with $\mathrm{GnRH}$ for up to $24 \mathrm{~h}$. In contrast, 
the expression of GnRH mRNA was decreased by GnRH treatment in a dose-dependent manner and the IL-2R $\gamma$ subunit gene was highly expressed in mononuclear cells. At this point we can speculate that these GnRH-binding sites in lymphocytes are probably functional, as many studies have demonstrated that $\mathrm{GnRH}$ a caused a dose-dependent increase in LH production, whereas GnRHR antibodies blocked this action (Chen et al., 1999).

It has also been shown that blockade of central and peripheral GnRHR with a potent GnRH antagonist (GnRH-ant) during a critical period of maturation can impair the morphological development of thymus and the cellular and humoral immune responses in rats (Morale et al., 1991) and monkeys (Mann et al., 1994).

Particularly, neonatal exposure of male primates to a GnRHant alters early postnatal programming of immune function by reducing the number of $\mathrm{B}$ cells and $\mathrm{T}$ cells in the thymic medulla and $\mathrm{T}$ cells in the periarterial lymphatic sheaths of the spleen. $\mathrm{GnRH}$-ant treatment increased the frequency of clinical problems, lowered circulating levels of lymphocytes, total $\mathrm{T}$ cells, CD8 $+\mathrm{T}$ cells and $\mathrm{B}$ cells, and altered the proliferative index of lymphocytes to mitogens. As adults, the cell- and humorallymediated immune responses remained impaired (Mann et al., 2000).

To evaluate regions of GnRH-I binding activity, a biotinylated GnRH-I sequence was used with avidin-labelled HRP, and results showed GnRH-I binding activity present in Kupffer cells, spleen lymphocytes and follicular dendritic cells, as well as in thymocytes and peripheral blood lymphocytes and neutrophils (Khan et al., 2003).

\section{GnRH AND IMMUNE SYSTEM}

GnRH and sex steroids seem to be important components of immune system modulation and may play a role in the regulation of immune mediated diseases. A comprehensive description of such interactions has been reviewed by Tanriverdi et al. (2003) and Quintanar (2011).

\section{Immune response to GnRH administration Proliferation}

Induction. When splenocytes and thymocytes are preincubated with GnRH-a or GnRH peptide, an augmentation of the proliferative response is obtained. Marchetti et al. (1989) showed a significant dose-dependent increase on proliferative response to the mitogen ConA in rat thymocytes. This response was abolished with simultaneous addition of a GnRH-ant. Also, splenocytes and thymocytes from proestrus female rats incubated with $\mathrm{GnRH}$ or its analogs, significantly increased the basal proliferative activity which was accompanied by a specific increase in IL-2 receptorpositive cells (Batticane et al., 1991).

Furthermore, in vivo GnRH-a treatment prevents thymus atrophy and markedly stimulates thymocyte blastogenic activity in hypophysectomized rats, thus suggesting that GnRH and its agonistic analogs are may capable to exert a direct modulation of immune system function (Marchetti et al., 1989).

Injection of GnRH-a increases CD8+ T-cell levels and proliferation to a variety of mitogens (Mann et al., 1994). In another study, it has been reported that $\mathrm{GnRH}$ immunization in rats induced the presence of eosinophils in intertubular tissue of testes whereas in unimmunized controls these cells were not present (Duckett et al., 1997).

Moreover, in a rat model of pregnancy-induced thymic involution, GnRH-a infusions markedly attenuated pregnancy-induced thymic involution resulting in significant increases in thymic weight and thymocyte numbers (Dixit et al., 2003a).

In the same way, Sutherland et al. (2008) made a pilot study in patients, where a GnRH-a (goserelin) was given prior to allogeneic or autologous hematopoietic stem cell transplantation. GnRH-a administration significantly increased neutrophil and lymphocyte numbers within the first month of posttransplantation indicating that either directly or indirectly, GnRH induced an increase in circulating neutrophils.

It has been reported that treatment with the GnRH-a, leuprolide acetate (50 $\mu \mathrm{g} / \mathrm{mouse}$, s.c.) prior to restraint stress, significantly prevented its effect on cell-mediated immunity, antibody titer levels, total leukocyte count and relative thymus weight, showing a significant increase of these immunological parameters (Umathe et al., 2008).

Supression. To test whether a GnRH-a could alter in vivo human immune cells, Ho et al. (1995) treated a group of infertile patients under a protocol of buserelin acetate administration and peripheral B cells, NK cells, CD4+ and CD8+ T cells, and the expression of CD69, CD25, human leucocyte antigen-DR (HLA-DR), and CD71 antigens on the $\mathrm{T}$ cells were serially examined by dual-color flow cytometry. They found that the GnRH-a had a transiently immunosuppressive effect on CD4+ and CD25+ T cells, but CD69+, CD25+, and HLA-DR+ T cells were activated during and after successful implantation. Regarding to the B cells, NK cells, CD8+ T cells, and CD71+ T lymphocyte subpopulations there were no changes throughout the whole course of treatment.

On the other hand, several groups have provided evidence that the in vitro proliferation of a variety of human ovarian, endometrial, and breast cancer cell lines can be inhibited by agonistic and/or antagonistic analogs of GnRH in a dose- and time-dependent manner (Eidne et al., 1987; Thompson et al., 1991; Emons et al., 1993a,b; Emons and Schally, 1994).

In ovarian cancer cells, GnRH seems to have two opposite activities:

1. The antimitotic activity through inhibition of signal transduction of mitogens such as epidermal growth factor, and

2. The inhibition of Doxorubicin-induced apoptosis via activation of transcription nuclear factor kappa B (NFkB) as shown by Gründker et al. (2000). In this report is clearly suggested that GnRH-a Triptorelin inhibits Doxorubicin-induced apoptosis via activation of NFkB.

Furthermore, biopsy specimens collected from lesions, myometria and corresponding endometria of women with ovarian endometrioma, adenomyosis and uterine myoma treated with the GnRH-a, leuprolide acetate, for a variable period of 3-6 months before surgery, showed a significantly decrease in the infiltration of CD68-positive $\mathrm{M} \phi$, micro-vessel density and tissue levels of monocyte chemotactic protein I (MCP-I). Furthermore, when compared with the non-treated group, a significant increase in apoptotic index and quantitative-histogram scores of activated 
caspase-3 after GnRH-a therapy were observed in the eutopic endometria, lesions and myometria of these diseases (Khan et al., 2010).

Tanriverdi et al. (2005) demonstrated that GnRH-I and GnRH-II have differential modulatory effects on human PBMC proliferation and IL-2R $\gamma$-chain mRNA expression in healthy males. Treatment of in vitro PMBCs with GnRH-I and with IL-2 resulted in a significant increase in cell proliferation as well as in an increased expression of IL-2R $\gamma$ mRNA in a dose dependent manner compared with the untreated control. In contrast, GnRH-II administration did not affect the proliferation of PMBCs alone, and IL-2R $\gamma$ expression was significantly decreased in all concentrations. This study clearly indicates the potential stimulatory effects of GnRH-I in PBMCs and reduction of these effects by GnRH-II.

Induces GnRH production by immune cells. Numerous interesting and solid studies show that T-cells (and other immune cells) can in fact produce and secrete various endogenous neurotransmitters, either spontaneously or after induction by external stimuli. Among neurotransmitters produced by T-cells are GnRH-I and GnRH-II (Levite, 2008).

Immunoactive and bioactive $\mathrm{GnRH}$ peptide is present and the $\mathrm{GnRH}$ message is expressed in human peripheral blood T-cells. Both $\mathrm{CD}^{+}$and $\mathrm{CD}^{+}{ }^{+}$subsets of T-cells produce $\mathrm{GnRH}$ and it is significantly increased when cells are activated by either phytohemagglutinin or anti-CD3 antibody. This GnRH production in activated T-cells is an early activation event that is independent of IL-2 system activation and DNA synthesis (Azad et al., 1993).

Induces immune mediators production. To investigate the role of $\mathrm{GnRH}$ in the modulation of $\mathrm{T}$ helper cytokines in pregnant rats undergoing termination of pregnancy, Dixit et al. (2003b) administrated a GnRH-a to evaluate effects on Th- 1 and Th- 2 cytokines. A marked increase in IFN- $\gamma$, inhibition of IL-4 production and an IL-2 and IL-10 absent response was observed. It is possible that IL-2 levels are unchanged because it might has been consumed by activated T cells (Quintanar, 2011).

Recently, Goldberg et al. (2009) demonstrated in a clinically relevant model of allogeneic bone marrow transplantation, that after leuprolide acetate treatment, the enhanced peripheral $\mathrm{T}$ cell reconstitution is due to both increases in lymphoid-committed precursors as well as enhanced thymic regeneration.

$\mathrm{GnRH}$ has also been reported to regulate four angiogenic chemokines expression (CXCL2, CXCL3, CXCL6, and CXCL8) in human placenta, where trophoblasts were subsequently shown to recruit lymphocytes. Additionally, in Jurkat $\mathrm{T}$ cells and primary peripheral blood T and uterine NK cells; chemokine release was detected in chemotaxis assays and this was shown to be $\mathrm{GnRH}$ dependent (Cavanagh et al., 2009).

There are two works evaluating the efficacy of the GnRH-a, leuprolide acetate, on NK cells activity in endometriosis. Results are contradictory since the first one suggests an increased NK cell activity in peripheral blood samples determined by $51 \mathrm{Cr}$ release assay (Umesaki et al., 1999); and the second one reported that NK cell cytotoxicity from control and patients was significantly decreased with leuprolide acetate (Wong and Simon, 2004). These findings suggest a direct immunomodulatory role of $\mathrm{GnRH}$ on NK cell activity.

In an attempt to know the possible immunomodulatory effects of GnRH on LPS activated human peripheral blood monocytes cultured in vitro, Komorowski and Stepien (1995) found that GnRH did not affect the secretion of the cytokines IL- $1 \beta$ and IL-6.

On the other hand, there is a report where the immunomodulation exerted by $\mathrm{GnRH}$ on freshly isolated primary peritoneal macrophages is clearly observed. In this work the authors found that the production of nitric oxide, co-stimulated with LPS and IFN $\gamma$, and the activity of NF-kB was suppressed by GnRH exposure. Taken together, these results demonstrate that GnRH participates in macrophage function and indicate that the NF-kB signaling pathway may be responsible for $\mathrm{GnRH}$-mediated immune modulation (Min et al., 2009).

\section{GnRH expression response against immune system challenges}

There is a work that reported that when lymphocyte lysates were applied to rat anterior pituitary cells in monolayer culture, significant stimulation of GnRH secretion was seen. This response evoked by lymphocyte lysates was found to be dose dependent and could be significantly inhibited by a GnRH-ant (Emanuele et al., 1990).

Otherwise, TNF has a number of regulatory actions on gonadotrophic functions: TNF and other cytokines, notably IL$1 \beta$, have powerful LH suppressing abilities on pituitary activity (Kalra et al., 1998).

\section{GnRH and autoimmunity}

Given that GnRH possesses direct immunostimulatory actions, it has been hypothesized that $\mathrm{GnRH}$ might play a role in the development of autoimmune disease.

Jacobson et al. (1994) demonstrated that the administration of $\mathrm{GnRH}$ antagonists in a mouse model of systemic lupus erythematosus (SLE), led to a reduction in autoantibody levels, total immunoglobulin levels, renal disease, and significantly improved survival, independently of gonadal steroids.

Based on the above mentioned findings and considering that (1) in the nonobese mouse model of autoimmune diabetes (NOD mouse), castration of male NOD mice leads to increased incidence of diabetes, and that (2) castration of male mice leads to an increase in GnRH action, Ansari et al. (2004) determined the effect of GnRH agonists and antagonists on expression of autoimmune diabetes in this mouse model. Their results showed that Antide administration prevented the increased incidence of diabetes, reduced total serum IgG levels, IL- 6 cytokine expression in cultured splenocytes, and the lymphocytic infiltration of islets. $\mathrm{GnRH}$ administration exerted reciprocal effects, leading to earlier timing of onset of diabetes and increased serum total IgG levels.

In addition, due to that has been reported that motoneurons of spinal cord of rat from embryonic until adult stage, express GnRHRs which respond to GnRH (Quintanar et al., 2009) a possible clinical use in spinal cord injury (Calderón-Vallejo and Quintanar, 2012) and CNS autoimmune diseases has been proposed. Specifically, treatment with GnRH (Quintanar, 2011) or a synthetic analog (Guzmán-Soto et al., 2012) induces an improvement of clinical signs in the EAE 
model, where they remained significantly lower in EAE rats with GnRH administration compared to animals without treatment. In these experiments, also a significantly increased expression of neurofilaments (NFs) and myelin basic protein as well as more axons of larger areas in the spinal cord of EAE animals were found.

A great advantage of $\mathrm{GnRH}$ and its analog leuprolide acetate, is that they are capable to cross the blood brain barrier (Kastin et al.,
1980; Barrera et al., 1991) and reach their targets into the CNS. Taking into account this advantage of leuprolide acetate and its effect on recovery in locomotion and increased expression of biological markers, the use of this agonist as a potential therapeutic approach for traumatic or neurodegenerative diseases such as multiple sclerosis should be considered.

The effects of GnRH on immune system are summarized in Figure 3.

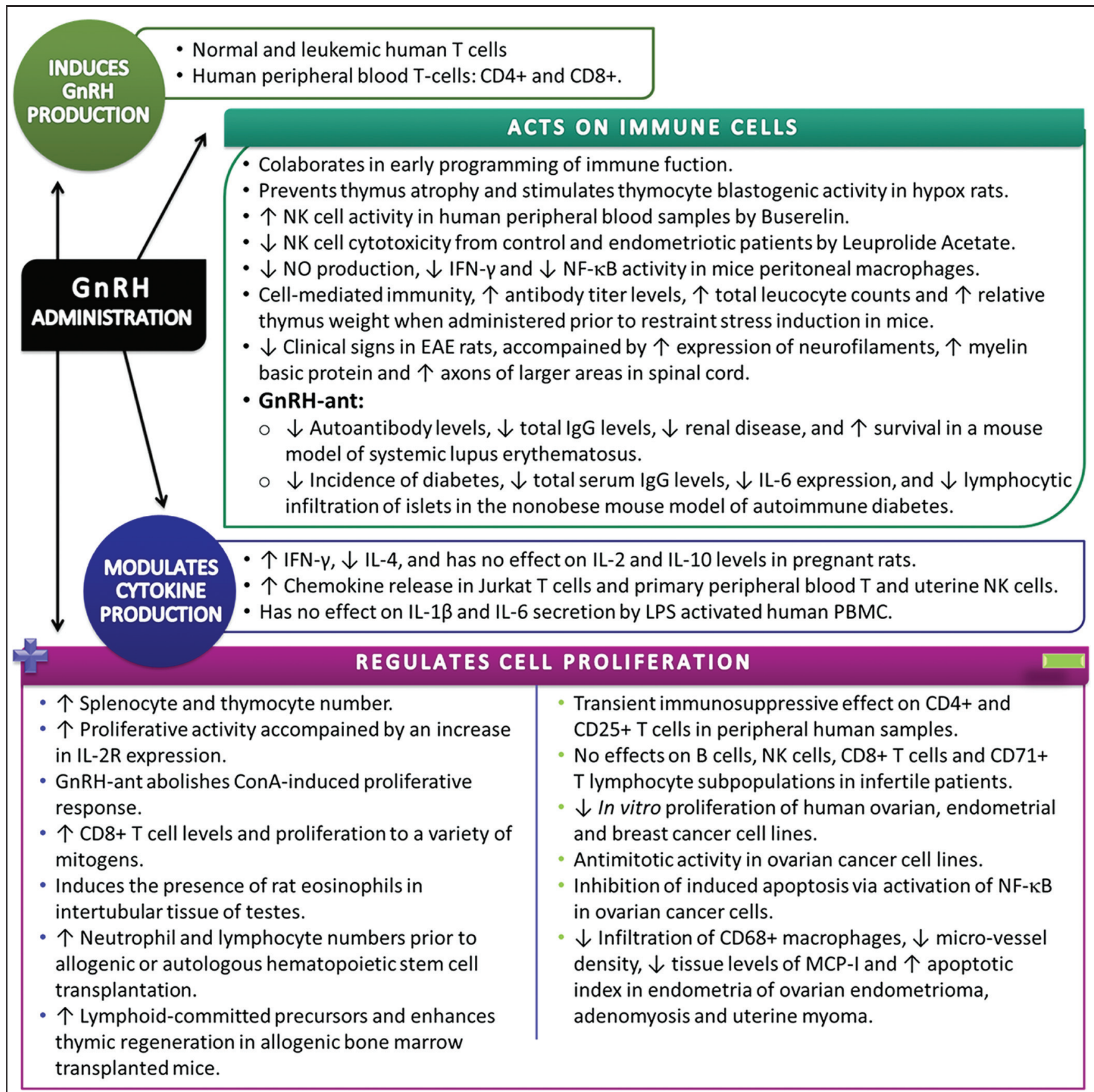

FIGURE 3 | Summary of experimental data showing the effects of Gonadotropin-Releasing Hormone/Gonadotropin-Releasing Hormone agonist on the immune system. Extrapituitary GnRH is implicated in a wide range of immunological processes, including direct cell immunomodulation and proliferative responses ( $\uparrow=$ increase, $\downarrow=$ decrease). 


\section{Clinical relevance and future directions}

GnRH induces the secretion of FSH-LH and consequently of sex hormones, which are involved in the immune response. Controversial is the idea that sex hormones are immunoprotective because depending on the type of hormone and experimental conditions can be obtained opposite effects.

The presence of $\mathrm{GnRH}$ receptors and $\mathrm{GnRH}$ secretion by cells of the immune system, opening the spectrum of possibilities for interaction of autocrine or paracrine regulation. However, the pharmacological use of GnRH or its analogues, independently of the direct effect of sex hormones, raise the possibility that can be used as a inflammatory regulator in autoimmune diseases. Retrospective studies can be analyzed to establish whether treatment with GnRH analogues have improved immunological conditions of patients with autoimmune pathology. This option can be explored in future works.

\section{CONCLUSION}

Hypothalamic hormones are closely related to the immune system. Their direct and indirect effects establish a bidirectional network to establish the required mechanisms to maintain homeostasis.

\section{REFERENCES}

Aguilera, G., Wynn, P. C., Harwood, J. P., Hauger, R. L., Millan, M. A., Grewe, C., et al. (1986). Receptor-mediated actions of corticotropin-releasing factor in pituitary gland and nervous system. Neuroendocrinology 43, 79-88. doi: 10.1159/000124513

Angioni, S., Petraglia, F., Gallineli, A., Cosarizza, A., Franceschi, C., Michela, M., et al. (1993). Corticotropin releasing hormone modulates cytokines release in cultured human peripheral blood mononuclear cells. Life Sci. 53, 17351742. doi: 10.1016/0024-3205(93) 90160-5

Ansari, M. A., Dhar, M., Spieker, S., Bakht, N., Rahman, A. M., Moore, W. V., et al. (2004). Modulation of diabetes with gonadotropin-releasing hormone antagonists in the nonobese mouse model of autoimmune diabetes. Endocrinology 145, 337-342. doi: 10.1210/en.2003-0512

Aten, R. F., Polan, M. L., Bayless, R., and Behrman, H. R. (1987). A gonadotropin-releasing hormone (GnRH)-like protein in human ovaries: similarity to the GnRH-like ovarian protein of the rat. J. Clin. Endocrinol. Metab. 64, 1288-1293. doi: 10.1210/jcem-64-6-1288

Audhya, T., Jain, R., and Hollander, C. S. (1991). Receptormediated immunomodulation by corticotropin-releasing factor. Cell. Immunol. 134, 77-84. doi: 10.1016/0008-8749(91)90332-6
Azad, N., Jurgens, J., Young, M., Reda, D., Duffner, L., and Kirsteins, L. (1991). Presence of luteinizing hormone-releasing hormone in rat thymus. Prog. Neuro. Endocr. Immunol. 4, 113-120.

Azad, N., La Paglia, N., Jurgens, K. A., Kirsteins, L., Emanuele, N. V., Kelley, M. R., et al. (1993). Immunoactivation enhances the concentration of luteinizing hormone-releasing hormone peptide and its gene expression in human peripheral T-lymphocytes. Endocrinology 133, 215-223. doi: 10.1210/en.133.1.215

Baigent, S. M., and Lowry, P. J. (2000). mRNA expression profiles for corticotrophin-releasing factor (CRF), urocortin, CRF receptors and CRF-binding protein in peripheral rat tissues. $J$. Mol. Endocrinol. 25, 43-52. doi: 10.1677/jme.0.0250043

Bale, T. L., and Vale, W. W. (2004). CRF and CRF receptors: role in stress responsivity and other behaviors. Annu. Rev. Pharmacol. Toxicol. 44, 525-557. doi: 10.1146/annurev. pharmtox.44.101802.121410

Barrera, C. M., Kastin, A. J., Fasold, M. B., and Banks, W. A. (1991). Bidirectional saturable transport of LHRH across the blood-brain barrier. Am. J. Physiol. 261, E312-E318.

Batticane, N., Morale, M. C., Gallo, F., Farinella, Z., and Marchetti, B. (1991). Luteinizing hormonereleasing hormone signaling at the lymphocyte involves stimulation of interleukin-2 receptor expression.

TRH, CRH and GnRH exhibit common patterns of specific receptors in immune cells and tissues. It is hard to think in the action of a single independent factor within the neuroimmunoendocrine network. When any of these elements destabilize, the system is altered and is difficult to define which factor of all may have been responsible for the alteration. Perhaps because of the complexity of the network, experiments to demonstrate such events become complicated to study. Using in vitro models allow clarify in a specific manner some of the elements involved in the homeostasis, however, extrapolate it to in vivo models could lead to unreliable interpretations.

In the evolution of the knowledge of the involvement of neurohormones on the immune system, we can find that many of the investigations are related to their pharmacological application, however, few of them concern to the physiological mechanism of its immunomodulation either autocrine or paracrine. If more is known about the physiology of these neurohormones, expectations about their applications at therapeutic level or to the understanding of our complex responses to internal or external challenges to maintain the survival of the individual could be proposed.

Endocrinology 129, 277-286. doi: 10.1210/endo-129-1-277

Besedovsky, H., del Rey, A., Sorkin, E., and Dinarello, C. A. (1986). Immunoregulatory feedback between interleukin-1 and glucocorticoid hormones. Science 233, 652-654. doi: 10.1126/science. 3014662

Bílek, R., Bicíková, M., and Šafarík, L. (2011). TRH-Like peptides. Physiol. Res. 60, 207-215.

Blum, C., Grozdea, J., and Vergnes, H. (1976). Cytochemical aspects of human polynuclear neutrophils under the in vitro and in vivo action of TRH. C. R. Seances Soc. Biol. Fil. 170, 666-671.

Boler, J., Enzmann, F., Folkers, K., Bowers, C. Y., and Shally, A. V. (1969). The identity of chemical and hormonal properties of the thyrotropin releasing hormone and pyroglutamyl-histidil-proline amide. Biochem. Biophys. Res. Commun. 37, 705-710. doi: 10.1016/0006$291 \times(69) 90868-7$

Boyadjieva, N., Advis, J. P., and Sarkar, D. K. (2006). Role of betaendorphin, corticotropin-releasing hormone and autonomic nervous system in mediation of the effect of chronic ethanol on natural killer cell cytolytic activity. Alcohol. Clin. Exp. Res. 30, 1761-1767. doi: 10.1111/j.1530-0277.2006.00209.x

Brod, S., and Bauer, V. (2013). Ingested (oral) thyrotropin releasing factor (TRH) inhibits EAE. Citokine 61, 323-328. doi: 10.1016/j.cyto.2012.10.015
Brouxhon, S. M., Prasad, A. V., Joseph, S. A., Felten, D. L., and Bellinger, D. L. (1998). Localization of corticotropin releasing factor in primary and secondary lymphoid organs of the rat. Brain Behav. Immun. 12, 107-122. doi: 10.1006/brbi.1998.0520

Burgus, R., Dunn, T. F., Desiderio, D., Vale, W., and Guillemin, R. (1969). Derives polypeptidiques de syntheses doues d'activite hypophysiotrope TRF. Nouvelles observations. C. R. Acad. Sci. Hebd. Seances Acad. Sci. D. 269, 226-228.

Calderón-Vallejo, D., and Quintanar, J. L. (2012). Gonadotropin-releasing hormone treatment improves locomotor activity, urinary function and neurofilament protein expression after spinal cord injury in ovariectomized rats. $\mathrm{Neu}$ rosci. Lett. 515, 187-190. doi: 10.1016/j.neulet.2012.03.052

Cao, J., Papadopoulou, N., Kempuraj, D., Boucher, W. S., Sugimoto, K. Cetrulo, C. L., et al. (2005). Human mast cells express corticotropinreleasing hormone $(\mathrm{CRH})$ receptors and $\mathrm{CRH}$ leads to selective secretion of vascular endothelial growth factor. J. Immunol. 174, 7665-7675.

Cavanagh, P. C., Dunk, C., Pampillo, M., Szereszewski, J. M., Taylor, J. E., Kahiri, C., et al. (2009). Gonadotropin-releasing hormoneregulated chemokine expression in human placentation. Am. J. Physiol. Cell Physiol. 297, 1727. doi: 10.1152/ajpcell.00013. 2009 
Chatzaki, E., Murphy, B. J., Wang, L., Million, M., Ohning, G. V., Crowe, P. D., et al. (2004). Differential profile of CRF receptor distribution in the rat stomach and duodenum assessed by newly developed CRF receptor antibodies. J. Neurochem. 88, 1-11. doi: 10.1046/j.1471-4159.2003.02078.x

Chen, A., Ganor, Y., Rahimipour, S., Ben-Aroya, N., Koch, Y., and Levite, M. (2002). The neuropeptides GnRH-II and GnRH-I are produced by human $\mathrm{T}$ cells and trigger laminin receptor gene expression, adhesion, chemotaxis and homing to specific organs. Nat. Med. 8, 1421-1426. doi: 10.1038/ $\mathrm{nm} 801$

Chen, H.-F., Jeung, E.-B., Stephenson, M., and Leung, P. C. K. (1999). Human peripheral blood mononuclear cells express GonadotropinReleasing Hormone (GnRH), $\mathrm{GnRH}$ receptor and interleukin2 receptor $\gamma$-chain messenger ribonucleic acids that are regulated by GnRH in vitro. J. Clin. Endocrinol. Metab. 84, 743-750. doi: 10.1210/jc.84.2.743

Chen, X. Q., Dong, J., Niu, C. Y., Fan, J. M., and Du, J. Z. (2007). Effects of hypoxia on glucose, insulin, glucagon and modulation by corticotropin-releasing factor receptor type 1 in the rat. Endocrinology 148, 3271-3278. doi: 10.1210/en.2006-1224

Cheng, C. K., and Leung, P. C. K. (2005). Molecular biology of gonadotropin-releasing hormone (GnRH)-I, GnRH-II and their receptors in humans. Endocr. Rev. 26, 283-306. doi: 10.1210/er.20030039

Cheung, L. W., and Wong, A. S. (2008). Gonadotropin-releasing hormone: GnRH receptor signaling in extrapituitary tissues. FEBS J. 275, 5479-5495. doi: 10.1111/j.17424658.2008.06677.x

Chiamolera, M. I., and Wondisford, F. E. (2009). Minireview: thyrotropinreleasing hormone and the thyroid hormone feedback mechanism. Endocrinology 150, 1091-1096. doi: 10.1210/en.2008-1795

Ciechanowska, M., Lapot, M., Mateusiak, K., and Przekop, F. (2010). Neuroendocrine regulation of $\mathrm{GnRH}$ release and expression of $\mathrm{GnRH}$ and GnRH receptor genes in the hypothalamus-pituitary unit in different physiological states. Reprod. Biol. 10, 85-124. doi: 10.1016/s1642-431x(12)60054-0

Clarke, I. J., and Pompolo, S. (2005). Synthesis and secretion of GnRH.
Anim. Reprod. Sci. 88, 29-55. doi: 10.1016/j.anireprosci.2005.05.003

Colson, A.-O., Perlman, J. H., Smolyar, A., Gershengorn, M. C., and Osman, R. (1998). Static and dynamic roles of extracellular loops in G-ProteinCoupled receptors: a mechanism for sequential binding of thyrotropinreleasing hormone to its receptor. Biophys. J. 74, 1087-1100. doi: 10.1016/s0006-3495(98)77827-0

Conn, P. M., and Janovick, J. A. (2009). Trafficking and quality control of the gonadotropin releasing hormone receptor in health and disease. Mol. Cell. Endocrinol. 299, 137-145. doi: 10.1016/j.mce.2008. 10.051

Dixit, V. D., Sridaran, R., Edmonsond, M. A., Taub, D., and Thompson, W. E. (2003a). Gonadotropin-releasing hormone attenuates pregnancyassociated thymic involution and modulates the expression of antiproliferative gene product prohibitin. Endocrinology 144, 14961505. doi: 10.1210/en.2002-220955

Dixit, V. D., Yang, H., Udhayakumar, V., and Sridaran, R. (2003b). Gonadotropin-releasing hormone alters the $\mathrm{T}$ helper cytokine balance in the pregnant rat. Biol. Reprod. 68, 2215-2221. doi: 10.1095/biolreprod.102.012211

Dong, K. W., Yu, K. L., and Roberts, J. L. (1993). Identification of a major up-stream transcription start site for the human progonadotropinreleasing hormone gene used in reproductive tissues and cell lines. Mol. Endocrinol. 7, 1654-1666. doi: 10.1210/me.7.12.1654

Duckett, R. J., Hedger, M. P., McLachlan, R. I., and Wreford, N. G. (1997). The effects of gonadotropin-releasing hormone immunization and recombinant follicle-stimulating hormone on the leydig cell and macrophage populations of the adult rat testis. $J$. Androl. 18, 417-423.

Dufau, M. L., Tinajero, J. C., and Fabbri, A. (1993). Corticotropinreleasing factor: an antireproductive hormone of the testis. FASEB J. 7, 299-307.

Eidne, K. A., Flanagan, C. A., Harris, N. S., and Millar, R. P. (1987). Gonadotropin-releasing hormone (GnRH)-binding sites in human breast cancer cell lines and inhibitory effects of GnRH antagonists. J. Clin. Endocrinol. Metab. 64, 425432. doi: 10.1210/jcem-64-3-425

Emanuele, N. V., Emanuele, M. A., Tentler, J., Kirsteins, L., Azad, N., and Lawrence, A. M. (1990). Rat spleen lymphocytes contain an immunoactive and bioactive luteinizing hormone-releasing hormone. Endocrinology 126, 2482-2486. doi: 10.1210/endo-1265-2482

Emeric-Sauval, E. (1986) Corticotropin-releasing factor (CRF) a review. Psychoneuroendocrinology 11, 277-294. doi: 10.1016/0306-4530(86)90014-4

Emons, G., and Schally, A. V. (1994). The use of luteinizing hormone releasing hormone agonists and antagonists in gynecological cancers. Hum. Reprod. 9, 1362-1379.

Emons, G., Schröder, B., Ortmann, O., Westphalen, S., Schulz, K. D., and Schally, A. V. (1993a). High affinity binding and direct antiproliferative effects of luteinizing hormone-releasing hormone analogs in human endometrial cancer cell lines. J. Clin. Endocrinol. Metab. 77, 1458-1464. doi: 10.1210/jc.77.6.1458

Emons, G., Ortmann, O., Becker, M., Irmer, G., Springer, B., Laun, R., et al. (1993b). High-affinity binding sites and direct antiproliferative effects of LHRH analogues in human ovarian cancer cell lines. Cancer Res. 53, 5439-5446. doi: 10.1210/jc.77.6.1458

Engel, S., Neumann, S., Kaur, N., Monga, V., Jain, R., Northup, J., et al. (2006). Low affinity analogs of thyrotropin-releasing hormone are super-agonists. J. Biol. Chem. 281, 3103-13109. doi: 10.1074/jbc.m600440200

Engler, D., Scanlon, M. F., and Jackson, I. M. D. (1981). Thyrotropinreleasing hormone in the systemic circulation of the neonatal rat is derived from the pancreas and other extraneural tissues. J. Clin. Invest. 67, 800-808. doi: 10.1172/jci 110097

Esposito, P., Chandler, N., Kandere, K., Basu, S., Jacobson, S., Conolly, R., et al. (2002). Corticotropin-releasing hormone and brain mast cells regulate BBB permeability induced by acute stress. J. Pharmacol. Exp. Therapeut. 303, 1061-1066. doi: 10.1124/jpet.102.038497

Feng, P., Carnell, N. E., Kim, U. J., Jacobs, S., and Wilber, J. F. (1992). The human testis: a novel locus for thyrotropin-releasing hormone (TRH) and TRH mRNA. Trans. Assoc. Am. Physicians 105, 222-228.

Fukusumi, S., Ogi, K., Onda, H., and Hinuma, S. (1995). Distribution of thyrotropin-releasing hormone receptor mRNA in rat peripheral tissues. Regul. Pept. 57, 115-121. doi: 10.1016/0167-0115(95)00026-8
Gary, K. A., Sevarino, K. A., Yarbrough, G. G., Prange, A. J. Jr., and Winokur, A. (2003). The thyrotropinreleasing hormone (TRH) hypothesis of homeostatic regulation: implications for TRH-based therapeutics. J. Pharmacol. Exp. Ther. 305, 410-416. doi: 10.1124/jpet.102. 044040

Gill, C. J., and Rissman, E. F. (1998). Mast cells in the neonate musk shrew brain: implications for neuroendocrine immune interactions. Brain Res. Dev. Brain Res. 111, 129-136. doi: 10.1016/s01653806(98)00121-7

Goldberg, G. L., King, C. G., Nejat, R. A., Suh, D. Y., Smith, O. M., Bretz, J. C., et al. (2009). Luteinizing hormone-releasing hormone enhances $\mathrm{T}$ cell recovery following allogeneic bone marrow transplantation. J. Immunol. 182, 5846-5854. doi: 10.4049/jimmunol.0801458

Grammatopoulos, D. K., and Chrousos, G. P. (2002). Functional characteristics of $\mathrm{CRH}$ receptors and potential clinical applications of CRH-receptor antagonists. Trends Endocrinol. Metab. 13, 436-444. doi: 10.1016/s1043-2760(02)00670-7

Grasso, G., Massai, L., De Leo, V., and Muscettola, M. (1998). The effect of LHRH and TRH on human Interferon-y production in vivo and in vitro. Life Sci. 62, 2005-2014. doi 10.1016/s0024-3205(98)00172-6

Gravanis, A., and Margioris, A. (2005). The corticotropin-releasing factor (CRF) family of neuropeptides in inflammation: potential therapeutic applications. Bioactive peptides for immune disease therapy. Curr. Med. Chem. 13, 1503-1512. doi: 10.2174/0929867054039008

Gründker, C., Schulz, K., Günthert, A. R., and Emons, G. (2000) Luteinizing hormone-releasing hormone induces nuclear factor kappa B-activation and inhibits apoptosis in ovarian cancer cells. J. Clin. Endocrinol. Metab. 85, 3815-3820. doi: 10.1210/jc.85.10.3815

Guillemin, R. (2005). Hypothalamic hormones a.k.a. hypothalamic releasing factors. J. Endocrinol. 184, 11-28. doi: 10.1677/joe.1.05883

Guzmán-Soto, I., Salinas, E., Hernández-Jasso, I., and Quintanar, J. L. (2012). Leuprolide acetate, a GnRH agonist, improves experimental autoimmune encephalomyelitis: a possible therapy for multiple sclerosis. Neurochem. Res. 37, 2190-2197. doi: 10.1007/s11064-012-0842-x

Haddad, E. E., and Mashaly, M. M. (1992). Augmentation of 
natural cell-mediated cytotoxic activity by supernatant from in vitro mitogen-stimulated, in vivo hormone-treated lymphocytes in immature male ( $\mathrm{K}$ strain) chickens. Immunol. Invest. 21, 365-375. doi: 10.3109/08820139209069376

Hagan, P., Poole, S., and Bristow, A. F. (1992). Immunosuppressive activity of corticotropin releasing factor: inhibition of IL-1 and IL-6 production by human mononuclear cells. Biochem. J. 281, 251-254.

Harbour, D. V., Kruger, T. E., Coppenhaver, D., Smith, E. M., and Meyer, W. J. (1981). Differential expression and regulation of thyrotropin (TSH) in T cell lines. Mol. Cell. Endocrinol. 64, 229-241. doi: 10.1016/0303-7207(89)90150-0

Harbuz, M. S., Stephanou, A., Sarlis, N., and Lightman, S. L. (1992). The effects of recombinant human IL-1-alpha, Il-1-beta or IL-6 on hypothalamic-pituitary-adrenal axis activation. J. Endocrinol. 133, 349-355.

Harris, G. W. (1948). Neural control of the pituitary gland. Physiol. Rev. 28, 139-179.

Harrison, G. S., Wierman, M. E., Nett, T. M., and Glode, L. M. (2004). Gonadotropin-releasing hormone and its receptor in normal and malignant cells. Endocr. Relat. Cancer 11, 725-748. doi: 10.1677/erc. 1.00777

Hart, R., Wagner, F., Steffens, W., Lersch, C., Dancygier, H., Duntas, L., et al. (1990). Effect of thyrotropin-releasing hormone on immune functions of peripheral blood mononuclear cells. Regul. Pept. 27, 335-342. doi: 10.1016/ 0167-0115(90)90122-d

Heinrichs, S. C., Cole, B. J., Pich, E. M., Menzaghi, F., Koob, G. F., and Hauger, R. L. (1992). Endogenous corticotropin-releasing factor modulates feeding induced by neuropeptide $\mathrm{Y}$ or a tail-pinch stressor. Peptides 13, 879-884. doi: 10.1016/0196-9781(92)90044-4

Hinkle, P. M., Gehret, A. U., and Jones, B. W. (2012). Desensitization, trafficking and resensitization of the pituitary thyrotropinreleasing hormone receptor. Front. Neurosci. 6:180. doi: 10.3389/fnins. 2012.00180

Ho, H. N., Chen, H. F., Chen, S. U., Chao, K. H., Yang, Y. S., Huang, S. C., et al. (1995). Gonadotropin releasing hormone $(\mathrm{GnRH})$ agonist induces down-regulation of the CD3+CD25+ lymphocyte subpopulation in peripheral blood. Am. J. Reprod. Immunol.
33, 243-252. doi: 10.1111/j.16000897.1995.tb00891.x

Inoue, K., Valdez, G. R., Reyes, T. M., Reinhardt, L. E., Tabarin, A., Rivier, J., et al. (2003). Human urocortin II, a selective agonist for the type 2 corticotropin-releasing factor receptor decreases feeding and drinking in the rat. J. Pharmacol. Exp. Ther. 305, 385-393. doi: 10.1124/jpet.102.047712

Irwin, M. R. (1993). Brain corticotropin releasing hormone and interleukin- $1 \beta$ induced suppression of specific antibody production. Endocrinology. 133, 1352-1360. doi: 10.1210/en.133.3.1352

Irwin, M. R., Vale, W., and Britton, K. T. (1987). Central corticotropinreleasing factor suppresses natural killer cytotoxicity. Brain Behav. Immun. 1, 81-87. doi: 10.1016/0889-1591(87)90009-2

Jacobson, J. D., Nisula, B. C., and Steinberg, A. D. (1994). Modulation of the expression of murine lupus by gonadotropin-releasing hormone analogs. Endocrinology 134, 2516-2523. doi: 10.1210/en.134.6. 2516

Janssen, D., and Kozicz, T. (2013). Is it really a matter of simple dualism? Corticotropin-releasing factor receptors in body and mental health. Front. Endocrinol. (Lausanne) 4:28. doi: 10.3389/fendo.2013.00028

Justice, N. J., Yuan, Z. F., Sawchenko, P. E., and Vale, W. (2008). Type 1 corticotropin-releasing factor receptor expression reported in BAC transgenic mice: implications for reconciling ligandreceptor mismatch in the central corticotropin-releasing factors system. J. Comp. Neurol. 511, 479-496. doi: 10.1002/cne.21848

Kalra, P. S., Edwards, T. G., Xu, B., Jain, M., and Kalra, S. P. (1998). The antigonadotropic effects of cytokines: the role of neuropeptides. Domest. Anim. Endocrinol. 15, 321-332. doi: 10.1016/s0739-7240(98)00030-7

Kamath, J., Yarbrough, G. G., Prange, A. J. Jr., and Winokur, A. (2009). The thyrotropin-releasing hormone (TRH)-immune system homeostatic hypothesis. Pharmacol. Ther. 121, 20-28. doi: 10.1016/j.pharmthera.2008.09.004

Karalis, K., Muglia, L. J., Bae, D., Hilderbrand, H., and Majzoub, J. A. (1997). CRH and the immune system. J. Neuroimmunol. 72, 131-136.

Kastin, A. J., Coy, D. H., Schally, A. V., and Zadina, J. E. (1980). Dissociation of effects of LH-RH analogs on pituitary regulation and reproductive behavior. Pharmacol.
Biochem. Behav. 13, 913-914. doi: 10.1016/0091-3057(80)90228-2

Kawahito, Y., Sano, H., Mukai, S., Asai, K., Kimura, S., Yamamura, Y., et al. (1995). Corticotropin releasing hormone in colonic mucosa in patients with ulcerative colitis. Gut 37, 544 551. doi: 10.1136/gut.37.4.544

Kawano, H., Daikoku, S., and Saito, S. (1983). Location of thyrotropin-releasing hormone-like immunoreactivity in rat pancreas. Endocrinology 112, 951-955. doi: 10.1210/endo-112-3-951

Kempuraj, D., Papadopoulou, N. G., Lytinas, M., Huang, M., KandereGrzybowska, K., Madhappan, B., et al. (2004). Corticotropin-releasing hormone and its structurally related urocortin are synthesized and secreted by human mast cells. Endocrinology 145, 43-48. doi: 10.1210/en.2003-0805

Khalil, M. H., Silverman, A. J., and Silver, R. (2003). Mast cells in the rat brain synthesize gonadotropinreleasing hormone. J. Neurobiol. 56, 113-124. doi: 10.1002/neu. 10220

Khan, K. N., Kitajima, M., Hiraki, K., Fujishita, A., Sekine, I., Ishimaru, T., et al. (2010). Changes in tissue inflammation, angiogenesis and apoptosis in endometriosis, adenomyosis and uterine myoma after GnRH agonist therapy. Hum. Reprod. 25, 642-653. doi: 10.1093/humrep/dep437

Khan, M. A., Ferro, V. A., and Stimson, W. H. (2003). Use of a highly specific monoclonal antibody against the central variable amino acid sequence of mammalian gonadotropin releasing hormone to evaluate GnRH-I tissue distribution compared with GnRH-I binding sites in adult male rats. Am. J. Reprod. Immunol. 49, 239-248. doi: 10.1034/j.1600-0897.2003.01202.x

Khomane, K. S., Meena, C. L., Jain, R., and Bansal, A. K. (2011). Novel thyrotropin-releasing hormone analogs: a patent review. Expert. Opin. Ther. Pat. 21, 1673-1691. doi: 10.1517/13543776.2011.623127

Kobayashi, H., Ishizuka, T., and Okayama, Y. (2000). Human mast cells and basophils as sources of cytokines. Clin. Exp. Allergy 30, 1205-1212. doi: 10.1046/j.13652222.2000.00808.x

Komorowski, J., and Stepien, H. (1995). Somatostatin (SRIF) stimulates the release of interleukin-6 (IL-6) from human peripheral blood monocytes (PBM) in vitro. Neuropeptides 29, 77-81. doi: 10.1016/01434179(95)90087-x
Komorowski, J., Stepled, H., and Pawlikowski, M. (1993). The evidence of thyroliberin/triiodothyronin control of TSH secretory response from human peripheral blood monocytes cultured in vitro. Neuropeptides 25, 31-34. doi: 10.1016/01434179(93)90065-i

Koob, G. F., and Heinrichs, S. C. (1999). A role for corticotrophin-releasing factor and urocortin in behavioral responses to stressors. Brain Res. 848, 141-152. doi: 10.1016/s00068993(99)01991-5

Korosi, A., Kozicz, T., Richter, J., Veening, J. G., Olivier, B., and Roubos, E. W. (2007). Corticotropin-releasing factor, urocortin 1, and their receptors in the mouse spinal cord. J. Comp. Neurol. 502, 973-989. doi: 10.1002/cne.21347

Koshida, H., and Kotake, Y. (1993). Thyrotropin-releasing hormone enhances the superoxide anion production of rabbit peritoneal macrophages stimulated with N-Formyl-Methionyl-LeucylPhenylalanine and opsonized zymosan. Life Sci. 53, 725-731. doi: 10.1016/0024-3205(93)90249-3

Kruger, T. E., Smith, L. R., Harbour, D. V., and Blalock, J. E. (1989). Thyrotropin: an endogenous regulator of the in vitro immune response. $J$. Immunol. 142, 744-747.

Kuhne, C., Puk, O., Graw, J., Hrabe de Angelis, M., Schutz, G., Wurst, W., et al. (2012). Visualizing corticotropin-releasing hormone receptor type 1 expression and neuronal connectivities in the mouse using a novel multifunctional allele. J. Comp. Neurol. 520, 3150-3180. doi: 10.1002/cne.23082

Kukain, E. M., Mutsenietse, R. K., and Klusha, V. E. (1982). Comparison of the neuro- and immunomodulator properties of low-molecular neuropeptides. Biull. Eksp. Biol. Med. 94, 79-82. doi: 10.1007/bf00830729

Kunert-Radek, J., Pawlikowski, M., Stepien, H., and Janecka, A. (1991). Inhibitory effect of thyrotropin releasing hormone on spontaneous proliferation of mouse spleen lymphocytes in vitro. Biochem. Biophys. Res. Commun. 181, 562565. doi: $10.1016 / 0006-291 \times(91)$ 91226-3

Lenz, H. J. (1987). Extrapituitary effects of corticotropin-releasing factor. Horm. Metab. Res. Suppl. 16, 17-23.

Lersch, C., Hammer, C., Krombach, F., and Dancygier, H. (1989). Effect of thyrotropin-releasing hormone (TRH) on the chemiluminescence (CL) activity of human mononu- 
clear cells. J. Clin. Lab. Immunol. 28, 69-71.

Lesnikov, V. A., Korneva, E. A., Dall'ara, A., and Pierpaoli, W. (1991). The involvement of pineal gland and melatonin in immunity and aging: II. Thyrotropin-releasing hormone and melatonin forestall involution and promote reconstitution of the thymus in anterior hypothalamic area (AHA)-lesioned mice. Int. J. Neurosci. 62, 141-153. doi: 10.3109/00207459108999767

Levite, M. (2008). Neurotransmitters activate T-cells and elicit crucial functions via neurotransmitter receptors. Curr. Opin. Pharmacol. 8, 460-471. doi: 10.1016/j.coph.2008. 05.001

Lewis, K., Li, C., Perrin, M. H., Blount, A., Kunitake, K., Donaldson, C., et al. (2001). Identification of urocortin III, an additional member of the corticotropin-releasing factor (CRF) family with high affinity for the CRF2 receptor. Proc. Natl. Acad. Sci. U S A 98, 7570-7575. doi: 10.1073/pnas.121165198

Limonta, P., and Manea, M. (2013). Gonadotropin-releasing hormone receptors as molecular therapeutic targets in prostate cancer: current options and emerging strategies. Cancer Treat. Rev. 39, 647-663. doi: 10.1016/j.ctrv.2012.12.003

Lovenberg, T. W., Chalmers, D. T., Liu, C., and DeSouza, E. B. (1995). CRF2 alpha and CRF2 beta receptor mRNAs are differentially distributed between the rat central nervous system and peripheral tissues. Endocrinology 136, 4139-4142. doi: 10.1210/en.136.9.4139

Magon, N. (2011). Gonadotropin releasing hormone agonists: expanding vistas. Indian J. Endocrinol. Metab. 15, 261-267. doi: 10.4103/2230-8210.85575

Maier, C., Marchetti, B., LeBoeuf, R., and Blalock, J. (1992). Thymocytes express a mRNA that is identical to hypothalamic luteinizing hormonereleasing hormone mRNA. Cell. Mol. Neurobiol. 12, 447-454. doi: 10.1007/bf00711545

Maillot, C., Million, M., Wei, J. Y., Gauthier, A., and Tache, Y. (2000). Peripheral corticotropin-releasing factor and stress-stimulated colonic motor activity involve type 1 receptor in rats. Gastroenterology 119, 1569-1579. doi: 10.1053/gast.2000.20251

Mann, D. R., Akinbami, M. A., Lunn, S. F., Fraser, H. M., Gould, K. G., and Ansari, A. A. (2000). Endocrineimmune interaction: alterations in immune function resulting from neonatal treatment with a $\mathrm{GnRH}$ antagonist and seasonality in male primates. Am. J. Reprod. Immunol. $44,30-40$.

Mann, D. R., Ansari, A. A., Akinbami, M. A., Wallen, K., Gould, K. G. and McClure, H. M. (1994). Neonatal treatment with luteinizing hormone releasing hormone analogs alters peripheral lymphocyte subsets and cellular and humorally mediated immune responses in juvenile and adult male monkeys. J. Clin. Endocrinol. Metab. 78, 292-298. doi: 10.1210/jc.78.2.292

Marchetti, B., Guarcello, V., Morale, M. C., Bartoloni, G., Farinella, Z., Cordaro, S., et al. (1989). Luteinizing hormone-releasing hormone binding sites in the rat thymus: characteristics and biological function. Endocrinology 125, 1025-1036. doi: 10.1210/endo-125-2-1025

Marchetti, B., Guarcello, V., Morale, M. C., Bartoloni, G., Palumbo, G. Jr., Raiti, F., et al. (1990). A physiological role for the neuropeptide luteinizing hormone-releasing hormone (LHRH) during the maturation of thymus gland function. Int. J. Neurosci. 51, 287-289. doi: 10.3109/00207459008999722

Marone, G. S., Galli, J., and Kitamura, Y. (2002). Probing the roles of mast cells and basophils in natural and acquired immunity, physiology and disease. Trends Immunol. 23, 425-427. doi: 10.1016/s14714906(02)02274-3

Martino, E., Nardi, M., Vaudagna, G., Simonetti, S., Cilotti, A., Pinchera, A., et al. (1980a). Thyrotropinreleasing hormone-like material in human retina. J. Endocrinol. Invest. 3, 267-271.

Martino, E., Nardi, M., Vaudagna, G., Simonetti, S., Cilotti, A., and Pinchera, A. (1980b). Presence of thyrotropin-releasing hormone in porcine and bovine retina. Experientia 36, 622-623. doi: 10.1007/bf01965840

Mastorakos, G., Karoutsou, E. I., and Mizamtsidi, M. (2006). Corticotropin releasing hormone and the immune/ inflammatory response. Eur. J. Endocrinol. 155, S77-S84.

Matre, V., Høvring, P. I., Fjeldheim, A. -K., Helgeland, L., Orvain, C., andersson, K. B., et al. (2003). The human neuroendocrine thyrotropin-releasing hormone receptor promoter is activated by the haematopoietic transcription factor c-Myb. Biochem. J. 372, 851-859. doi: 10.1042/bj20030057

McArdle, C. A., Franklin, J., Green, L., and Hislop, J. N. (2002). Signalling, cycling and desensitisation of gonadotrophin-releasing hormone receptors. J. Endocrinol. 173, 1-11. doi: 10.1677/joe.0.1730001

McEvoy, A. N., Bresnihan, B., FitzGerald, O., and Murphy, E. P. (2001). Corticotropin-releasing hormone signaling in synovial tissue from patients with early inflammatory arthritis is mediated by the type 1 corticotropin-releasing hormone receptor. Arthritis Rheum. 44, 1761-1767.

Mellado, M., Fernández-Agulló, T., Rodríguez-Frade, J. M., García San Frutos, M., de la Peña, P., MartínezA, C., et al. (1999). Expression analysis of the thyrotropin-releasing hormone receptor (TRHR) in the immune system using agonist anti-TRHR monoclonal antibodies. FEBS Lett. 451, 308-314. doi: 10.1016/s0014-5793(99)00607-9

Millar, R. P. (2005). GnRHs and GnRH receptors. Anim. Reprod. Sci. 88, 5-28. doi: 10.1016/j.anireprosci.2005.05.032

Min, J. Y., Park, M. H., Lee, J. K., Kim, H. J., and Park, Y. K. (2009). Gonadotropin-releasing hormone modulates immune system function via the nuclear factor-kappa B pathway in murine Raw264.7 macrophages. Neuroimmunomodulation 16, 177-184.

Monga, V., Meena, C. L., Rajput, S., Pawar, C., Sharma, S. S., Lu, X., et al. (2011). Synthesis, receptor binding and CNS pharmacological studies of new thyrotropin-releasing hormone (TRH) analogues. Chem. Med. Chem. 6, 531-543. doi: 10.1002/cmdc.201000481

Montagne, J.-J., Ladram, A., Nicolas, P., and Bulant, M. (1999). Cloning of thyrotropin-releasing hormone precursor and receptor in rat thymus, adrenal gland and testis. Endocrinology 140, 1054-1059. doi: 10.1210/en.140.3.1054

Morale, M. C., Batticane, N., Bartoloni, G., Guarcello, V., Farinella, Z., Galasso, M. G., et al. (1991). Blockade of central and peripheral luteinizing hormone-releasing hormone (LHRH) receptors in neonatal rats with a potent LHRH-antagonist inhibits the morphofunctional development of the thymus and maturation of the cell-mediated and humoral immune responses. Endocrinology 128, 10731085. doi: 10.1210/endo-128-21073

Morley, J. E. (1979). Extrahypothalamic thyrotropin-releasing hormone (TRH) - its distribution and its functions. Life Sci. 25, 1539-
1550. doi: 10.1016/0024-3205(79) 90435-1

Mousa, S. A., Bopaiah, C. P., Stein, C., and Schafer, M. (2003). Involvement of corticotropin-releasing hormone receptor subtypes 1 and 2 in peripheral opioid mediated inhibition of inflammatory pain. Pain 106, 297-307. doi: 10.1016/s03043959(03)00302-6

Müller, M. B., Preil, J., Renner, U., Zimmermann, S., Kresse, A. E., Stalla, G. K., et al. (2001). Expression of CRHR 1 and CRHR 2 in mouse pituitary and adrenal gland: implications for HPA system regulation. Endocrinology 142, 4150-4153. doi: 10.1210/en.142.9.4150

Nappi, R. E., and Rivest, S. (1995). Stress-induced genetic expression of a selective corticotropin-releasing factor-receptor subtype within the rat ovaries: an effect dependent on the ovulatory cycle. Biol. Reprod. 53, 1417-1428. doi: 10.1095/biolreprod53.6.1417

Nillni, E. A., and Sevarino, K. A. (1999). The biology of pro-thyrotropinreleasing hormone-derived peptides. Endocr. Rev. 20, 599-648. doi: 10.1210/er.20.5.599

Oikawa, M., Dargan, C., Ny, T., and Hsueh, A. J. (1990). Expression of gonadotropin releasing hormone and prothymosin-messenger ribonucleic acid in the ovary. Endocrinology 127, 2350-2356. doi: 10.1210/endo-127-5-2350

Pawlikowski, M., Zerek-Melen, G., and Winczyk, K. (1992). Thyroliberin (TRH) increases thymus cell proliferation in rats. Neuropeptides 23, 199-202. doi: 10.1016/01434179(92)90123-e

Pekary, A. E., Meyera, N. V., Vaillanta, C., and Hershmana, J. M. (1980). Thyrotropin-releasing hormone and a homologous peptide in the male rat reproductive system. Biochem. Biophys. Res. Commun. 95, 993-1000. doi: 10.1016/0006291x(80)91571-5

Pekary, A. E., Ross, R., de Kernion, J., and Hershman, J. M. (1983a). Human reproductive tissues contain thyrotropin releasing hormone (TRH) and TRH-homologous peptides. J. Androl. 4, 408-414.

Pekary, A. E., Richkind, M., and Hershman, J. M. (1983b). Thyrotrophin releasing hormone and related peptides in canine tissues. J. Endocrinol. 98, 299-306. doi: 10.1677/joe.0.0980299

Peng, C., Fan, N. C., Ligier, M., Vaananen, J., and Leung, P. C. K. (1994). Expression and regulation of gonadotropin-releasing 
hormone $(\mathrm{GnRH})$ and $\mathrm{GnRH}$ receptor messenger ribonucleic acids in human granulosa-luteal cells. Endocrinology 135, 1740-1746. doi: 10.1210/en.135.5.1740

Pérez Castro, C., Peñalva, R., Páez Pereda, M., Renner, U., Reul, J. M., Stalla, G. K., et al. (1999). Early activation of ThyrotropinReleasing-Hormone and prolactin plays a critical role during a $\mathrm{T}$ cell-dependent immune response. Endocrinology 140, 690-697. doi: 10.1210/en.140.2.690

Quintanar, J. L. (2011). Neuroimmunomodulation by Gonadotropin Releasing Hormone. Adv. Neuroimmune Biol. 1, 125-132.

Quintanar, J. L., Salinas, E. and González, R. (2009). Gonadotropinreleasing hormone receptor in spinal cord neurons of embryos and adult rats. Neurosci. Lett. 461, 21-24. doi: 10.1016/j.neulet.2009. 06.028

Quintanar, J. L., Salinas, E., and Quintanar-Stephano, A. (2011). Gonadotropin-releasing hormone reduces the severity of experimental autoimmune encephalomyelitis, a model of multiple sclerosis. Neuropeptides 45, 43-48. doi: 10.1016/j.npep.2010.10.003

Radulovic, M., and Spiess, J. (2001). Immunomodulatory role of the Corticotropin-Releasing Factor. Arch. Immunol. Ther. Exp. (Warsz) 49, 33-38.

Radulovic, M., Dautzenberg, F. M., Shydow, S., Radulovic, J., and Spiess, J. (1999). Corticotropin-releasing factor receptor 1 in a mouse spleen: expression after immune stimulation and identification of receptorbearing cells. J. Immunol. 162, 3013 3021.

Raiden, S., Polack, E., Nahmod, V., Labeur, M., Holsboer, F., and Arzt, E. (1995). TRH receptor on immune cells: in vitro and in vivo stimulation of human lymphocyte and rat splenocyte DNA synthesis by TRH. J. Clin. Immunol. 15, 242-249. doi: 10.1007/bf01540881

Raux-Demay, M. C., and Girard, F. (1985). The physiology of corticotropin-releasing factor (CRF). Reprod. Nutr. Dev. 25, 931-943.

Sapolsky, R., Rivier, C., Yamamoto, G., Plotsky, P., and Vale, W. (1987). Interleukin-I stimulates the secretion of hypothalamic corticotropinreleasing factor. Science 238, 522 524. doi: 10.1126/science.2821621

Sasaki, K., and Norwitz, E. R. (2011). Gonadotropin-releasing hormone/gonadotropin-releasing hormone receptor signaling in the placenta. Curr. Opin. Endocrinol. Diabetes Obes. 18, 401-408. doi: 10.1097/MED.0b013e32834cd3b0

Satoh, T., Feng, P., Kim, U. J., and Wilber, J. F. (1993). Identification of thyrotropin releasing hormone receptor messenger RNA in the rat central nervous system and eye. Brain Res. Mol. Brain Res. 19, 175-178. doi: 10.1016/0169$328 \mathrm{x}(93) 90165-1$

Schaeffer, J. M., Brownstein, M. J., and Axelrod, J. (1977). Thyrotropinreleasing hormone-like material in the rat retina: changes due to environmental lighting. Proc. Natl. Acad. Sci. U S A 74, 3579-3581. doi: 10.1073/pnas.74.8.3579

Scharrer, E., and Scharrer, B. (1940). Secretory cells within the hypothalamus. Res. Publ. Assoc. Res. Nerv. Ment. Dis. 20, 170-194.

Schürmeyer, T. H., Avgerinos, P. C., Gold, P. W., Gallucci, W. T., Tomai, T. P., Cutler, G. B. Jr., et al. (1984). Human corticotropinreleasing factor in man: pharmacokinetic properties and doseresponse of plasma adrenocorticotropin and cortisol secretion. J. Clin. Endocrinol. Metab. 59, 1103-1108. doi: 10.1210/jcem-596-1103

Shambaugh, G., Kubek, M., and Wilber, J. F. (1979). Thyrotropin-releasing hormone activity in the human placenta. J. Clin. Endocrinol. Metab. 48, 483-486. doi: 10.1210/jcem-483-483

Silverman, A. J., Millar, R. P., King, J. A., Zhuang, X., and Silver, R. (1994). Mast cells with gonadotropinreleasing hormone-like immunoreactivity in the brain of doves. Proc. Natl. Acad. Sci. US A 91, 3695-3699. doi: 10.1073/pnas.91.9.3695

Singh, V. K., and Fudenberg, H. H. (1988). Binding of [125I] corticotropin releasing factor to blood immunocytes and its reduction in Alzheimer's disease. Immunol. Lett. 18, 5-8. doi: 10.1016/01652478(88)90061-2

Singh, V. K., and Leu, S. J. (1990). Enhancing effect of corticotropinreleasing neurohormone on the production of interleukin-1 and interleukin-2. Neurosci. Lett. 120, 151-154. doi: 10.1016/03043940(90)90025-5

Singh, V. K., Warren, R. P., White, E. D., and Leu, S. J. C. (1990). Corticotropin-releasing factorinduced stimulation of immune functions. Ann. N Y Acad. Sci. 594, 416-419. doi: 10.1111/j.1749. 6632.1990.tb40514.x
Singh, V. K. (1989). Stimulatory effect of corticotropin-releasing neurohormone on human lymphocyte proliferation and interleukin-2 receptor expression. J. Neuroimmunol. 23, 257-262. doi: 10.1016/0165-5728(89)90058-1

Slominski, A., Ermak, G., Hwang, J., Chakraborty, A., Mazurkiewicz, J. E., and Mihm, M. (1995). Proopiomelanocortin, corticotrophinreleasing hormone and corticotrophin releasing hormone receptor genes are expressed in human skin. FEBS Lett. 374, 113-116.

Song, J. P., Chen, X., and $\mathrm{Hu}, \mathrm{S}$. (2013). Corticotropin releasing hormone activates CD14+ cells to induce endothelial barrier dysfunction. Cell Biol. Int. 37. doi: 10.1002/cbin.10133. [Epub ahead of print].

Standaert, F. E., Chew, B. P., De Avila, D., and Reeves, J. J. (1992). Presence of luteinizing hormonereleasing hormone binding sites in cultured porcine lymphocytes. Biol. Reprod. 46, 997-1000. doi: 10.1095/biolreprod46.6.997

Stevenson, T. J., Hahn, T. P., MacDougall-Shackleton, S. A., and Ball, G. F. (2012). Gonadotropinreleasing hormone plasticity: a comparative perspective. Front. Neuroendocrinol. 33, 287-300. doi: 10.1016/j.yfrne.2012.09.001

Strausbaug, H., and Irwin, M. (1992). Central corticotropin releasing hormone reduces cellular immunity. Brain Behav. Immun. 6, 11-17. doi: 10.1016/0889-1591(92)90055-s

Sun, Y., Lu, X., and Gershengorn, M. C. (2003). Thyrotropin-releasing hormone receptors - similarities and differences. J. Mol. Endocrinol. 30, 87-97. doi: 10.1677/jme.0.0300087

Sutherland, J. S., Spyroglou, L., Muirhead, J. L., Heng, T. S., PrietoHinojosa, A., Prince, H. M., et al. (2008). Enhanced immune system regeneration in humans following allogeneic or autologous hemopoietic stem cell transplantation by temporary sex steroid blockade. Clin. Cancer Res. 14, 1138-1149. doi: 10.1158/1078-0432.ccr-07-1784

Tan, O., and Bukulmez, O. (2011). Biochemistry, molecular biology and cell biology of gonadotropin-releasing hormone antagonists. Curr. Opin. Obstet. Gynecol. 23, 238-244. doi: 10.1097/gco.0b013e328348a3ce

Tanriverdi, F., Gonzalez-Martinez, D., $\mathrm{Hu}$, Y., Kelestimur, F., and Bouloux, P. M. (2005). GnRH-I and GnRHII have differential modulatory effects on human peripheral blood mononuclear cell proliferation and interleukin-2 receptor gammachain mRNA expression in healthy males. Clin. Exp. Immunol. 142, 103-110.

Tanriverdi, F., Silveira, L. F., MacColl, G. S., and Bouloux, P. M. (2003). The hypothalamicpituitary-gonadal axis: immune function and autoimmunity. J. Endocrinol. 176, 293-304. doi: 10.1677/joe.0.1760293

Theoharides, T. C., and Cochrane, D. E. (2004). Critical role of mast cells in inflammatory diseases and the effect of acute stress. J. Neuroimmunol. 146, 1-12. doi: 10.1016/j.jneuroim.2003.10.041

Theoharides, T. C., Singh, L. K., Boucher, W., Pang, X., Letourneau, R., Webster, E., et al. (1998). Corticotropin-releasing hormone induces skin mast cell degranulation and increased vascular permeability, a possible explanation for its proinflammatory effects. Endocrinology 139, 403-413. doi: 10.1210/en.139.1.403

Thompson, M. A., Adelson, M. D., and Kaufman, L. M. (1991). Lupron retards proliferation of ovarian epithelial tumour cells cultured in serum-free medium. J. Clin. Endocrinol. Metab. 72, 1036-1041. doi: 10.1210/jcem-72-5-1036

Umathe, S. N., Dixit, P. V., Wanjari, M. M., and Ullewar, M. P. (2008). Leuprolide-a GnRH agonist-prevents restraint stressinduced immunosuppression via sex steroid-independent peripheral mechanism in mice. Int. Immunopharmacol. 8, 71-79. doi: 10.1016/j.intimp.2007.10.011

Umesaki, N., Tanaka, T., Miyama, M., Mizuno, K., Kawamura, N., and Ogita, S. (1999). Increased natural killer cell activities in patients treated with gonadotropin releasing hormone agonist. Gynecol. Obstet. Invest. 48, 66-68. doi: 10.1159/000010137

Vaughan, J., Donaldson, C., Bittencourt, J., Perrin, M. H., Lewis, K., Sutton, S., et al. (1995). Urocortin, a mammalian neuropeptide related to fish urotensin I and to corticotropin-releasing factor. Nature 378, 287-292. doi: 10.1038/378287a0

Walters, K., Wegorzewska, I. N., Chin, Y. P., Parikh, M. G., and Wu, T. J. (2008). Luteinizing hormonereleasing hormone I (LHRH-I) and its metabolite in peripheral tissues. Exp. Biol. Med. 233, 123-130. doi: 10.3181/0707-mr-201 
Wang, J., Whetsell, M., and Klein, J. R. (1997). Local hormone networks and intestinal $\mathrm{T}$ cell homeostasis. Science 275, 1937-1939. doi: $\quad 10.1126 /$ science. 275.5308 . 1937

Wang, W., Zhang, X., Yang, L., Liu, D., Liu, G., and Zhou, J. (2012). Lipopolysaccharide upregulates the expression of corticotropinreleasing hormone via MAP kinase pathway in rat peritoneal macrophages. Mol. Cell. Biochem. 361, 1-7. doi: 10.1007/s11010-0111080-2

Webster, E. L., Tracey, D. E., Jutila, M. A., Wolfe, S. A. Jr., and de Souza, E. B. (1990). Corticotropin-releasing factor receptors in mouse spleen: identification of receptor-bearing cells as resident macrophages. Endocrinology 127, 440-452. doi: 10.1210/endo-127-1-440
Wilson, A. C., Meethal, S. V., Bowen, R. L., and Atwood, C. S. (2007). Leuprolide acetate: a drug of diverse clinical applications. Expert Opin. Investig. Drugs 16, 1-13. doi: 10.1517/13543784.16.11.1851

Winczyk, K., and Pawlikowski, M. (2000). Time of day-dependent effects of thyroliberin and thyrotropin on thymocyte proliferation in rats. Neuroimmunomodulation 7 , 89-91. doi: 10.1159/000026425

Wong, K. H., and Simon, J. A. (2004). In vitro effect of gonadotropinreleasing hormone agonist on natural killer cell cytolysis in women with and without endometriosis. Am. J. Obstet. Gynecol. 190, 44-49. doi: 10.1016/j.ajog.2003.08.032

Wright, I. M. R. (2003). Corticotropinreleasing hormone causes vasodilation in human skin via mast cell-dependent pathways. J. Clin.
Endocrinol. Metab. 88, 5427-5432. doi: $10.1210 / j \mathrm{jc}$ 2003-030377

Wynn, P. C., Harwood, J. P., Catt, K. J., and Aguilera, G. (1985). Regulation of corticotrophin releasing factor (CRF) receptors in the rat pituitary gland: effects of adrenalectomy on CRF receptors and corticotroph responses. Endocrinology 116, 1653-1659. doi: 10.1210/endo116-4-1653

Yin, W., and Gore, A. C. (2006). Neuroendocrine control of reproductive aging: roles of GnRH neurons. Reproduction 131, 403-414. doi: 10.1530/rep.1.00617

Conflict of Interest Statement: The authors declare that the research was conducted in the absence of any commercial or financial relationships that could be construed as a potential conflict of interest.
Received: 31 May 2013; paper pending published: 20 June 2013; accepted: 16 July 2013; published online: 13 August 2013.

Citation: Quintanar JL and Guzmán-Soto I (2013) Hypothalamic neurohormones and immune responses. Front. Integr. Neurosci. 7:56. doi: 10.3389/fnint.2013. 00056

Copyright () 2013 Quintanar and Guzmán-Soto. This is an open-access article distributed under the terms of the Creative Commons Attribution License (CC BY). The use, distribution or reproduction in other forums is permitted, provided the original author(s) or licensor are credited and that the original publication in this journal is cited, in accordance with accepted academic practice. No use, distribution or reproduction is permitted which does not comply with these terms. 